\title{
Çukurova'da Kuva-yı Milliye Yapılanmasının Temel Özellikleri
}

\author{
Prof. Dr. Şerife YORULMAZ*
}

\section{Özet}

Bu çaltşmantn amact, Milli Mücadele'de Çukurova'da, özellikle de doğu kısmında oluşturulan Kuva-yı Milliye'den hareketle söz konusu örgütlenmenin, yapısal özelliklerini ortaya koymaktır. Önce Sivas Kongresi'nden itibaren bölgede Kuva-yı Milliye'nin oluşumunda Mustafa Kemal'in yönlendirmeleri üzerinde durulmaktadır. Arkasından, bölgedeki Fransız işgalinin niteliği ve bunda Ermenilerin rolü vurgulanmaktadır. Bölgede propaganda ve yanıltıcı haberler yayma, yerel seçkinin işgal karşısındaki tavrı, köylülerin rolü, örgütlenmenin ekonomik altyapısı, yani cephane ve iaşe sorunu ayrl ayrl incelenmektedir. Bölgedeki Kuvayi Milliye'nin askeri yapıst konusunda ise; sırastyla çetecilik, müfreze ve bölük sistemine geçiş, örgütlenme sorunlarl ve Kuva-yi Milliye'nin lağvı ele alınmakta; son olarak, Güney Cephesinde başarı kazanıldıktan sonra, buradaki kuvvetlerin Batı Cephesine kaydırılmasına değinilmektedir.

\section{The Basic Characteristics of Kuva-yı Milliye Structuring in Çukurova Region}

\section{Abstract}

The aim of this study is to display the structural characteristics of Kuva-yt Milliye during the National Strife in Çukurova region in general and the east of the region in particular. First, Mustafa Kemal's guidances will be discussed during the establishment of Kuva-yl Milliye in this region before the Sivas Congress. Then, the characteristics of the French occupation and the role of Armenians in this respect will be pointed out. Propaganda, spreading of fallacious news, attitudes of the local elite towards the occupation, role of the peasants, economic background of the organization, i.e. armoury and sustenance in this region will be dealt separately. Regarding the military structure of Kuvayi Milliye in this region, guerilla fighting, the transition towards battalion and squad systems, problems of organization and

• Mersin Üniversitesi, Fen-Edebiyat Fakültesi, Tarih Bölümü Öğretim Üyesi. 
the abrogation of Kuvayi Milliye will be dealt with. As a last point, the transition of the forces to West Front after the success in the South Front will be discussed.

Milli Mücadele, Güney Cephesi boyutuyla bir çok çalışmaya konu oluşturmuştur. Ayrıca konuyla ilgili hatıralarda da ayrıntılı bilgiler bulunmaktadır. Burada yazışma ve hatıralardan da yararlanarak, özellikle Çukurova bölgesinde Kuva-yı Milliye oluşumunun düşünsel, siyasal ve askeri karakteri üzerinde durulmaya çalışılacaktır. Böylece bölge Kuva-yı Milliye'sinin yapısal özellikleri ve farklılıkları ortaya konulmuş olacaktır.

$\mathrm{Bu}$ yapısal çözümlemelere geçmeden önce, bölgenin işgali kısaca özetlenecek olursa; bilindiği gibi, Güney Anadolu, Birinci Dünya Savaşı içinde işgale uğramadığı halde, Mondros Ateşkes Anlaşması'nın 7. ve 10. maddelerine dayanılarak ve gerçekte 16 Mayıs 1916 tarihli Sykes-Picot Anlaşması'nı uygulamaya koymak amacıyla işgal ${ }^{1}$ edilmiştir. Önce İngilizlerin ve sonra Fransızların İskenderun, Adana ve Mersin bölgesini işgalleri şöyle gerçekleşmişti: 9 Kasım 1918'de, İskenderun'dan sonra Amanos dağlarıyla Payas çizgisi arasındaki bölgeye ilerlemişler ve 12 Ekim 1918 'de de İngiliz Generali Clark, 2. Ordu Komutanı Nihat Paşa'ya verdiği notada, 14 Aralık 1918'e kadar Osmanlı birliklerinin tümünün Pozantı'nın batısına geçmesini bildirmiştir. Nihat Paşa, bunu Mütareke koşullarına aykırı bularak karşı çıkmış ve birtakım önlemler almaya çalışmıştır. Fakat Tevfik Paşa hükümeti, durumu değerlendirdikten sonra, Adana ve dolaylarının Pozantı'ya kadar boşaltılmasını zorunlu bulmuş ve karar orduya iletilmiştir. 11 Aralık 1918'de Dörtyol işgal edilmiş, 17 Aralık 1918'de Fransızlar Mersin'e asker çıkarmış ve yine aynı tarihte Fransız Suriye işgal Ordusu Komutanı General Hamlin Adana'ya girmiştir. İşgal harekâtı genişlemiş; 8 Mart 1919'da Kozan'a Yüzbaşı Taillardat ile Üsteğmen Suby, Ceyhan'a ise Yüzbaşı Arrikhi gönderilmiştir ${ }^{2}$. Çukurova'nın işgali üzerine bir çok acı olay yaşanmış ve bu olaylar nedeniyle bölge Fransızlarla birlikte İngilizlerin bir yıl kadar ortak işgalinde kalmıştır. 1 Kasım 1919 tarihinden itibaren ise Maraş, Antep ve Urfa ile birlikte tümüyle Fransız işgali altına girmiştir ${ }^{3}$.

Bu arada İstanbul Hükümeti'nin, Toros dağlarını doğal sınır kabul ederek Adana'yı gözden çıkardığı anlaşılmaktadır ${ }^{4}$. İşgalin arkasından, bölge

13 Ocak 1916'da Sykes-Picot sözleşmesi olarak bilinen bir sözleşme ile Güney Anadolu ve Arapların yaşadığı toprakların geleceği hakkında kararlar verilmiştir. 9-16 Mayıs 1916'da ikinci bir "Sykes Picot" anlaşması yapılmıştır. Bu anlaşma bir önceki (3 Ocak 1916 tarihli) sözleşmeyi tamamlamış ve Irak, Suriye ve Güney Anadolu bölgelerinde İngiltere ve Fransa için paylar verilmesi kararlaştırılmıștır. Bkz. Türk İstiklal Harbi, IV. Cilt, Güney Cephesi, Genelkurmay Başkanlığı Harp Dairesi Resmi Yayınları, Ankara 1966, s.3; Gotthart Jeaschke, Türk Kurtuluş Savaşı Kronolojisi, Cilt.1, Ankara, 1970, s. 64.

2 Kasım Ener, Cukurova Kurtulus Savașinda Adana Cephesi, Türkiye Kuva-yı Milliye Mücahit ve Gazileri Cemiyeti Yayınları, Ankara, 1970, s. 32-33.

${ }^{3}$ Bige Yavuz, Kurtulus Savaşı Döneminde Türk-Fransız Ilişkileri 1919-1922, Türk Tarih Kurumu Yayınları, Ankara 1994, s.8.

${ }^{4}$ Uluğ İ̆demir, Sivas Kongresi Tutanakları, Türk Tarih Kurumu Yayınları, Ankara, 1969, s. 86; Rauf Bey'in Sivas Kongresi'nin 9-10 Eylül 1919 Çarşamba gecesi yapılan altıncı 
halkı kendi başının çaresine bakmak durumunda kalmış ve işgalci Fransızlar ile işbirlikçi Ermenilere karşı büyük bir direniş hareketi başlatmışlardır ${ }^{5}$. Halkın bu tutumu üzerine Sivas Kongresi'nde de, Adana bölgesinde Kuva-yı Milliye'nin kurulması kararı alınmıştır.

\section{Kuva-yı Milliye'nin Oluşumunda Mustafa Kemal'in Yönlendirmeleri}

Mustafa Kemal, Sivas Kongresi'nde yaptığı konuşmada, "Trakya'da, Kilikya'da ve her tarafta milli cemiyetler teşekkül etti. Hülasa garptan ve şarktan yükselen seda-yı millet, Anadolu'nun en ücra köşesinde mâkes buldu. Binaenaleyh milli cemiyetler, düşmanların esaret boyunduruğuna girmemek kasdıyla milli vicdanın azim ve iradesinden doğmuş yegâne teşkilat oldu. $\mathrm{Bu}$ sayede asırlardan beri müstakil yaşayan milletimiz mevcudiyetini aleme göstermeye başladı" diyerek işgale karşı direniş'in yapılanmasından söz etmiştir.

Sivas Kongresi sonunda, 11 Eylül 1919'da yayınlanan “Umumi Kongre Beyannamesi"nin 2. maddesinde, Kuva-yı Milliye'nin kurulmasıyla ilgili karar: "Camia-i Osmaniyenin tamamiyeti ve istiklal-i milliyemizin temini ve Makam-1 Mualla-yı Hilafet ve Saltanat'ın masuniyeti için kuva-yı milliye'yi amil ve irade-i milliyeyi hâkim kılmak, esas-1 kat'idir" ${ }^{\text {"7 }}$ şeklinde belitilmiştir.

Bölgenin durumu ise, Heyet-i Temsiliye'nin 22 Eylül 1919 tarihli genelgesinde ${ }^{8}$ şu şekilde anlatılmaktadır;

“Ateşkes sonrasında hükümetimiz Adana ili ile Antep, Maraş, Urfa sancaklarını bırakma güçsüzlüğünde bulunması, bu yörede Fransız ve İngiliz koruyuculuğu altında Ermeni işgalini ve örgütlenmesini kesinleştirmiş ve bunlar o il ve sancaklarl Ermenileştirmek amacıyla bir yıla yakın süre çalışma göstermiş ve çok üzücü ki, büyük çoğunluğu kendilerinde olmasına karşın, şimdiye dek örgütten yoksun bulunan Türklerin bireysel özverililikleri verimli olmamış ve her gün saldıran Ermeniler, çalışmalarını amaçları doğrultusunda yürütmüşlerdir.

Anadolu ve Rumeli Müdafaa-i Hukuk Cemiyeti, ülkemizde üzerinde bulunan bütün İslamları bir amaç çevresinde toplamış ve

toplantısındaki "Sadrazamın Toros dağlarını hudud-u tabiiye addederek Adana'yı terk ettiğini konferansa tebliğ ettiğini biliyorsam da..." sözleri.

5 Güneyde ilk Kuva-yı Milliye birliği, Dörtyol yakınlarında Aralık 1918'de kurulmuştur. Fransız ve Ermenilerin savunmasız halka saldırmaları üzerine Kuzuculu Köyünün gençleri kendi olanaklarıyla bir birlik oluşturmuşlardı. Buna yakın köylerin de katılmasıyla Kara Hasan birliğinin mevcudu 300'e ulaşmışır. Bkz. Türk İstiklal Harbi, IV. Cilt, s.236-237.

${ }^{6}$ A.g.e., ss.108-109.

${ }^{7}$ A.g.e., s.113.

${ }^{8}$ Mustafa Onar, Atatürk'ün Kurtuluş Savaşı Yazış̧aları , Cilt I, Kültür Bakanlığı Yayınları, Ankara, 1995, ss.183-184. 
Ateşkesin onaylandığ gün işgalimiz altında kalan sıntrlar içinde hiç bir yurt parçasının düşmana verilmemesini kararlaştırmış bulunduğundan yabancı işgali altında çă̆dışı işkencelere tutulan Adana ili ile Maraş, Antep, Urfa sancaklarının karşı karşıya kaldıkları durumlara ilgisiz kalınamayacă̆ kesinlikle bilinmelidir. Bu nedenle, Hıristiyan ve yabancı halkın şimdiye dek yapmış oldukları saldırıları hızla durdurmak ve belirtilen yörede bulunan büyük çoğunluğu oluşturan Müslümanlarla, her uygar ulus gibi, onlarl anayurttan uzaklaştırmak ve kovmak için 20, 13, 3,12. kolordularla sinırlı bulunan ulusal örgütün olağanüstü yardımlarına dayanarak adı geçen il ve sancakların güçlü biçimde örgütlenmelerini hızla oluşturmaya ve düşmanların saldırılarını önlemeye karar vermiştir."

Genelgede, Kuva-yı Milliye'nin oluşturulmasını zorunlu hale getiren düşmanın saldırı ve işgal yöntemleri şu şekilde vurgulanmaktaydı:

a. Fransız ve İngiliz görevlileri ile Ermeni komitelerinin ve oralarda bulunan Ermeni topluluğunun açıktan açığa Müslümanların haklarına saldırıları.

b. Osmanlı topraklarının değişik yerlerinde oturan Ermenilerin buralara göçlerinin kolaylaştırılması ve burada sayılarının artırılması.

c. Yabancı üniforması ile Ermeni birliklerinin buralara gönderilmesi ve buradakilerle birleştirilmesi.

d. Buradaki Müslüman halkın az zamanda ekonomik ve başka baskılarla yok edilmesi, öldürülmesi ve göçe zorlanması.

e. Aralarına aşamalı olarak sokulan bölücülükle İslam halkının yabancı koruyuculuğunu istemek zorunda birakılması.

Genelgede, bu durum karşısında yapılacak işler de belirtilmekteydi. Buna göre, alışveriş Müslümanlar arasında yapılacaktır. Ulusal birlik için ne olursa olsun birleşilecektir. Buna karşı olanlar hemen cezalandırılacaklardır. Jandarma, polis gibi güvenlik görevlerine, köy ve orman bekçiliğine olabildiğince çok Müslüman girecek, hükümet gücü elde tutulmaya çalışılacaktır. Örgüt elebaşlarını iyi tutmak, karşıt elebaşıları sessizce ortadan kaldırmaktır. Bu iki sorunu gerçekleştirmek için özverili kişiler hazırlanmalıdır.

Mustafa Kemal, Harbiye Nazırı Cemal Paşa'ya Amasya'dan gönderdiği 23.10.1919 tarihli yazıda, Adana şehri içinde Ermenilerin silahlandırıldı̆̆ Müslümanlarla çatışmaya sevk edildikleri ve Müslümanlar arasında büyük bir heyecan ve galeyan olduğu ve bu heyecanın Ulukışla çevresine kadar yayıldığının, o bölgeden gizli olarak bildirildiğini belirtmektedir ${ }^{9}$.

\footnotetext{
${ }^{9}$ Askeri Tarih Belgeleri Dergisi, sayı:103, Ocak 1997, s.24; belge no. 2864.
} 
Mustafa Kemal, Niğde'de 11.Tümen Komutanı Mümtaz Bey’e Sivas'tan yazdığı 23/24.10.1919 tarihli yazıda da; Adana bölgesindeki durumla ilgili hükümetin siyasi düşüncesinin sorulduğu, bu anlaşılıncaya kadar orada meydana gelen durumu ayrıntılarıyla araştırmalarını ister. Yazıya devamla, "Ulukışla'da teşkilatın takviye edilmesi ve özellikle seyyar milli müfreze oluşturulması gerekmektedir. Bunların sizin gözetiminiz altında istedikleri beş yüz tüfeğin usulüne uygun olarak verilmesi uygundur. Ancak şimdiden Adana havalisine geçmeyip tarafımızdan verilecek talimat ve tarafınızdan düzenlenecek şekilde hareket etmek üzere beklemeleri gerekmektedir" ${ }^{\prime 10}$ demektedir.

Bu durumdan örgütlenme ve çalışmaların, işgal bölgesinin sınırlarında konuşlandığı anlaşılmaktadır. Böylece daha sonraki karşı hareketler için zemin hazırlanmış oluyordu. Bu şekilde işgal alanı bir şekilde kuşatılmış oluyordu.

Çukurova'da Kuva-yı Milliye'nin örgütlenmesinde önemli rol oynayan Osman Tufan hatıralarında, Sivas Kongresi dağıldıktan sonra Heyet-i Temsiliye ile Salih Paşa heyeti arasında yapılacak görüşmeler için Mustafa Kemal'in Amasya'ya gittiği sırada (18-22 Ekim 1919) Sivas'ta bulundukları binanın koridorlarında, mahcup, çekingen tavırlı ve yolcu kıyafetiyle üç yabancı kişi gördüğünü ve onlarla konuştuğunu belirtir. Bu kişiler Kozan'dan geldiklerini, halkın Fransız ve Ermenilerden çektikleri zulmü anlatmak ve halkın bağımsızlığa kavuşabilmesi için Mustafa Kemal'le görüşmeye geldiklerini dile getirirler. Bu heyet, Hulusi Kurtoğlu, Dava Vekili Emmi Mustafa ve Halil Topaloğlu'ndan oluşmaktaydı. Heyet, bir akşam Sivas Kongresi salonunda Mustafa Kemal'in başkanlığında Heyet-i Temsiliye ile görüşür ve amaçlarının anlatır. Sonuçta Mustafa Kemal, Adana bölgesinde milli cephenin açılmasını emretmiş ${ }^{11}$ ve Topçu Binbaşı Kemal ile Yüzbaşı Osman'ı görevlendirmiştir. Mustafa Kemal bu görevi verirken, bir harita üzerinde, başarı yollarını da göstermiştir. Kozan yetkilileri, Adana bölgesi halkının silah ve cephanesinin, Birinci Dünya Savașı'ndan saklanmıș olarak yanlarında bulunduğunu, halkın böyle bir harekatı idareye maddi açıdan durumunun yeterli olduğunu, zahire ambarlarının da dolu olduğunu ve Sivas'tan verilecek emirle düşmana saldıracaklarını belirtmişlerdir.

Mustafa Kemal'in verdiği emre göre; teşkilat Kongre'de hazırlanan nizamnameye göre yapılacaktı. Sivas'tan hareketleri gizli tutulacak, Binbaşı Kemal "Kozanoğlu Doğan” takma adıyla Kilikya Komutanlığı'na, Yüzbaşı Osman ise "Aydınoğlu Tufan" takma adıyla Kilikya Komutan Yardımcılığı'na tayin edilmiști. Birtakım zorluklarla başlayan yolculuğun güzergahı, Kayseri-Develi-Haçın-Kozan'dır. Kozan heyetiyle Develi'de

${ }^{10}$ Askeri Tarih Belgeleri Dergisi, sayı:103, Ocak 1997, s.27; belge no. 2865.

"Osman Tufan., Kilikya Doğu Bölgesinde Milli Hareketler ve Kozan Sancağı ile Mülhakatının Kurtuluş Hatıraları, Bahar Matbaası, Ankara, 1964, s.32. 
buluşurlar. Heyet, teşkilatın hazırlıklarının Develi'de yapılması için çalışmalarına başlar ${ }^{12}$.

Mustafa Kemal, Amasya'dan Osman (Tufan) ve Recep Zühtü Beylere gönderdiği 19 Ekim 1919 tarihli telgrafta, "Ulusal ayaklanmaya karşı küstahlık edenler için yapılacak işlem gerekenlere bildirilmiştir. Durumu izleyerek eksiksiz uygulanıp uygulanmadığını bildirmenizi ve savsaklama görülürse, işe kendiniz el koyarak bilinen kişileri tutuklamanızı, her kime karşı olursa olsun, gereğini yapmakta duraksamaya gerek yoktur"'13 diyerek, Milli Mücadele'de başarıya ulaşmak ve bozgunculuğa karşı birlik ve beraberliğin sağlanabilmesi için disiplinin önemini vurgulamıştır. Ayrıca bu telgraf, Doğu Kilikya bölgesinde Kuva-yı Milliye'yi örgütlemekle görevli olan Osman Tufan'ın, anılarında da söz etmiş olduğu zorluklar ve sorunlarla ilgili ipuçları vermektedir.

İngiltere ve Fransa'nın yaptıkları pazarlıklar sonucu, İngilizlerin boşalttığı güney illerinin bu defa Fransızlar tarafından işgalinin söz konusu olması üzerine Mustafa Kemal'in, buralardan yapılan başvuruları da dikkate alarak bölgede Kuva-yı Milliye'nin oluşumu yönünde harekete geçtiği görülmektedir. Örneğin, Sivas'tan Heyet-i Temsiliye adına Maraş Mutasarrıflığı'na gönderdiği 31.10.1919 tarihli yazıda; her türlü siyasi tedbirlere başvurulmaya başlandığını, hukuki ve siyasi müracaatlara, protestolara önem vermedikleri takdirde fiilen savunma ve karşı koymak için milli teşkilatın hazırlık derecesinin acilen bildirilmesini ${ }^{14}$ istemektedir.

$\mathrm{Bu}$ arada Maraş'ta başlamış olan direniş hareketi devam etmektedir. Maraş direnişinin diğer bölgelere de yayılması için kolordular ve Kazım (Özalp) ile Refet (Bele)'den görüş istenmiş ve hepsinden olumlu yanıt alınmıştır. 25 Ocak 1920 tarihli şifreli yazıda Mustafa Kemal;

"Fransızların kuvvet getirerek olayı kanlı biçimde bastıracakları ve halkın parça parça edilmesi olasıdır. Bunu engellemek için her yerde, büyük küçük ulusal müfrezelerle harekete geçmeye zorunluk vardır. Gerçi bu hareketin, Aydın'da olduğu gibi bir cephe durumuna gelmesi kısa sürede gerçekleşmese de, şu andaki sessizliğin işgal bölgesi ile ona komşu bölgelerde her türlü yaşamı durduracă̆ından hareketin ertelenmesi olanaksızdır. Barış Konferansında geçici olarak işgal edilen yerlerin alınamayacă̆ı, Adana bölgesinde de görülmelidir. Bu görüşle, ulusal harekete başlanmast ve önce Urfa bölgesinde geniş ölçekte ve özellikle Fransiz işgal bölgelerinin daha doğusunda gerilla biçiminde harekete geçilmesi gerektiği görüşündeyiz.." demektedir ${ }^{15}$.

Aynı tarihli ve kolordulara gönderilen bir genelgede de;

${ }^{12}$ Tufan, a.g.e., ss.33-35.

${ }^{13}$ Onar, a.g.e., Cilt.I, s.263; Söylev, Cilt.I, s.185

${ }^{14}$ Askeri Tarih Belgeleri Dergisi, sayı:103, Ocak 1997, s.62; belge no.2876.

${ }^{15}$ Onar, a.g.e., Cilt.I, s.403. 
"Genel duruma göre Ulusal Kuvvetlerin Fransızlara karşı harekete geçmesini daha çok geciktirmek sakıncalı ve zararlıdır. Barış görüşmelerinin sonuçlandırılmak istendiği bu aşamada ulusumuzu kurtarmak için en büyük gücümüzü göstereceğimize Avrupalıların kuşkusu bulunmamalıdır. Bu da ancak hareketle sağlanabilir"

dendikten sonra, Fransızlara karşı koymanın biçimi şöyle açıklanmaktadır;

"Birliklerini ayrı ayrı ve birden bire bulundukları yerde kuşatmak ve bundan sonra Ulusal Kuvvetler aracılığı ile en küçük garnizonlarından başlayarak tutsak ve yok etmektir. Kuşatma önlemleri; tren köprülerini ve tünellerini atmak, yollar, otomobilleri işleyemeyecek durumda kesmek, güçleri ne denli olursa olsun kesinlikle bir müfrezemizle tutuşturmaktır. Bu karşı koyuşta başarının gizi, bağlantılarının kopuk tutuluşudur. Böylelikle, cephe kurulması gibi bizim için düşmandan daha çok ağırlık verecek ve politik sakıncalar getirecek düzenlerden de olabildiğince kaçınılmış olunur. Karşı koyma evreleri arka arkasına düzenlenecektir. Birinci evre Urfa'nin direnişidir" ${ }^{16}$.

Cephelerin görevleri, amaçları, eylem biçimleri ise şöyle açıklanmaktadır; 13. Kolordu'nun görevi Fırat'ın doğusunu bıraktırmaktır. Urfa direnişi döneminde Maraş cephesinin gelişimine göre hareket edilecek. Fransızlar, Maraş'ta işgallerini genişleterek ilerleyecek olurlarsa, Üçüncü Kolordu buna tüm silahlarıyla karşı koyacaktı. İşgallerini genişletmeyip Maraş'ta kalırlarsa, ne kadar yakın olursa olsun Maraş-Pazarcık garnizonunun gerisine yetişecek yere dek ulaşım ve vurucu müfrezelerini gönderecekti. Kozan bölgesinde de en yakın Fransız garnizonu gerisine müfreze gönderecekti. Bu cephelerde Ulusal Kuvvetlerin büyük çoğunluğu eyleme hazırlanacaktı. 20. Kolordu cephesinde çabuklukla müfrezeler hazırlanacak ve işgal bölgesine gitmek için bekleyecekti ${ }^{17}$.

Bu arada Fransızların Suriye'deki durumu da izlenmektedir. Mustafa Kemal, Sivas Valiliği'ne gönderdiği 6 Şubat 1920 tarihli telgrafta, Fransızların Suriye'de Araplarla çarpışmaya tutuştuklarını ve dolayısıyla Suriye'deki kuvvetlerinin, Adana'daki kuvvetlerine yardım edemeyeceğinin kesinleşmekte olduğunu ${ }^{18}$ belirtir.

Fransızların, Ulusal Kuvvetlerle düşman olmak istemedikleri yönündeki bildirimlerinin ve barışçı görünür politikalarının asılsız olduğu ve oyalama taktiği olduğunun, eylemlerinden anlaşılması üzerine Ulusal Kuvvetlerin eylemlerini artırmaları kararlaştırılmıştır. 11 Şubat 1920 tarihli ve ilgili komutanlıklara gönderilen şifreli yazıda Mustafa Kemal 20. Kolordu'nun, Adana kuzeyine ve kuzeydoğusuna Ulusal Birlikler göndererek, Adana

\footnotetext{
${ }^{16}$ A.g.e., Cilt.I, s.403.

${ }^{17}$ A.g.e., Cilt.I, s.404-405.

${ }_{18}$ A.g.e., Cilt.I, s.420; Nimet Arsan, Atatürk'ün Tamim Telgraf ve Beyannameleri, Atatürk Araştırma Merkezi Yayınları, Ankara, 1991, s.185; belge no.569.
} 
Fransız komutanlığına bildirmeden, Adana-İslahiye demiryolu üzerindeki köprü ve tünellerden hangilerini çabuk bozabilecekse onları bozacak ve onarımına olanak vermeyecek durumu sokacaktı. 20. Kolordu ise Haçın Ermenilerinin kuzeye saldırılarını engelleyecekti ${ }^{19}$. Anlaşıldığı üzere Fransa'nın işgal politikasını değiştirmemesi üzerine, milli teşkilatın yaygınlaştırılarak eyleme geçilmesine neden olmuştur.

Müdafa-i Hukuk şubelerine bildirimlerde bulunarak, halk desteği elde edilmeye çalışılmakta, bu şekilde Kuva-yı Milliye örgütlenmesi güçlendirilmek istenmektedir.

Mustafa Kemal'in 29 Mart 1920 tarihli ve 3. Kolordu Komutanı Selahattin Bey'e gönderdiği şifreli yazıda da, Fransızların genel kuvvetleri konusunda bilgi ${ }^{20}$ verildikten sonra, Antep ve Maraş yönünde düşmanın hareketini engellemek üzere 20. ve 12. kolorduların Haçın, Sis, Mersin dolaylarında bulunan Ulusal Kuvvetler müfrezelerinin daha çok çaba göstermeleri gerektiği tarafından yinelenmiştir ${ }^{21}$.

Bütün bunlardan Mustafa Kemal'in, bölgedeki gelişmeleri titizlikle izleyerek ve işgalci Fransızlarla diplomatik ilişkilerin aldığı biçim çerçevesinde durumu değerlendirerek gerekli yönlendirmeleri yapmış olduğu anlaşılmaktadır.

\section{Fransız İşgalinin Niteliği ve Ermeni Unsuru}

Gerçekte bir çıkar çatışması olan Birinci Dünya Savaşı'nın sona ermesine rağmen bu defa 19.yüzyıl ortalarından itibaren yapılan yatırım ve verilen borçların yani ekonomik çıkarlarının geleceğinin güvence altına alınması gündeme gelecek ve İngiltere'nin İtilaf Devletlerinin sözcüsü durumuna geçerek Anadolu'da üstünlük sağlaması ve buradaki İngiliz, Fransız ve İtalyan çıkarlarını çatışmaya döndürmesi üzerine Fransa ve İtalya, İngiltere-İstanbul Hükümeti ortaklığı karşısında yeni bir seçenek aramaya yönelecektir. Yani burada söz konusu olan, bu ülkelerin Osmanlı topraklarındaki ekonomik yatırımlarının ve borçların güvence altına alınmasıydı ${ }^{22}$. 21 Aralık 1918'de Adana'yı işgal eden Fransızlar, 9 Ocak 1919'da Albay Brémond'u Genel Valiliğe getirmişlerdir ${ }^{23}$. Sancak ve ilçelere Governeur olarak subaylar tayin etmek suretiyle, Osmanlı idare örgütünün üstünde bir Fransız kontrol idaresi kurmuşlardır. Bundan sonra Fransızlar, Kilikya bölgesinde jandarma gücünü düzenlemek bahanesiyle jandarma kuvvetlerini Ermeni askerlerde oluşturmaya kalkıştılar ${ }^{24}$. Bu önemliydi. Belki de Bağımsız Ermenistan'ın kurulması yönünde atılmış bir adımdı. Çünkü öteden beri burada bir Ermeni yönetimi kurulacağı

\footnotetext{
${ }^{19}$ Onar. a.g.e., Cilt.I, s.430, belge no. 588 .

${ }^{20}$ Fransızların doğuda dört tümeni bulunmaktadır. Bunlardan ikisi İstanbul'da, biri Suriye'de ve birisi de Kilikya'da parçalı bir durumdadır.

${ }^{21}$ Harp Tarihi Vesikaları Dergisi, sayı.13, belge no.347.

${ }^{22}$ Yavuz, a.g.e., s.20.

${ }^{23}$ Türk İstiklal Harbi, IV. Cilt, s.18.

${ }^{24}$ A.g.e., s.19.
} 
söyleniyordu. Adana eski Valisi Hazım Bey'in 23 Aralık 1918'de Padişah'a gönderdiği bir telgrafta bu konuya değinilerek Fransa'nın başta gelen amaçlarından birinin Kilikya'da bir Ermeni idaresi kurmak olduğu belirtilmekteydi. Fransızların Suriye'de meydana getirdikleri "Légion Arménienne" veya Ermenice adıyla "Gamavur" denilen Ermeni gönüllüleri de Fransızlarla birlikte bu bölgeye gelmişlerdi.

Ermeniler bölgede ancak nüfusun yüzde yirmisini oluşturmaktaydı ${ }^{25}$. Brémond, Fransızların Suriye'deki Ermeniler için genel bir planı olmadığını ve sadece bir mektuptan söz edildiğini ileri sürmektedir. Onun belirttiğine göre, Halep'te bulunan Colonel Clouscard bazı planlar uygulamaktadır. Bazı günler düzensiz olarak gelen trenlerle 3000 Ermeniyi habersiz olarak Adana'ya gönderiyordu. Bu nedenle onları barındırmak için topraktan tuğla barakalar inşa edilmekteydi. Bu şekilde bazı kampların oluşturulduğu anlaşılmaktadır. Bunlardan Faubourg Rolland'da 600-800 kişi, Picol Kampı'nda 3000-4000 kişi, Gouraud Kampı'nda ise 2000-3000 kişi barınmaktaydı. İşyerleri, atölye ve okullar yapılarak organizasyon sağlanıyordu. Aynı zamanda Ermenilerin gruplaşmasıyla Adana'da yığılma olmaması için, eski köyler yeniden kurulmaktaydı. 1919 yılı sonlarında 60 000'den fazla kiși bu șekilde yerleștirilmiști. 1919 sonlarında Kilikya nüfusu 400000 olup bunun 120 000'ini Ermeni nüfusu olușturmaktayd ${ }^{26}$. Fransızların desteğiyle geri dönen Ermenilerin 1920'de bölgede trajik olayların başlamasına neden olduğu bilinmektedir.

Bu konuda Osmanlı hükümetinin güçsüzlüğünü, Dışişleri Bakanlığı'nın Şubat 1919 tarihli aşă̆ıdaki yazısı açık bir şekilde göstermektedir;

"Adana Vilayeti Allenby tarafından kontrol altına alınmıştır. Tecavüzün siyaseten önüne geçmek mümkün değildir. itilaf makamları, mütareke barış demek değildir, harb hali, vuruşma olmaksızın devam etmektedir diyorlar; teşebbüslerimizi tetkik ve müzakere dahi etmiyorlar, bu suretle Itilaf Devletleri derece derece yaptıkları istilaya, güya savaşarak yapılmış bir işgal süsü vererek hareket ediyorlar. Siyaset yolu ile yapılacak bir şey kalmamıştır; nezaretlerden gelecek bu yoldaki iş'arları bundan sonra bilgi kabilinden telakkiye mecburuz"27.

Harbiye Nazırı Cemal Paşa, 3. Kolordu Komutanlığı'na gönderdiği 28.10.1919 tarihli ve 4274 sayılı yazıda, elde ettikleri bir bilgiyi ve alınacak önlemleri belirtmektedir. Söz konusu yazıda; Ermenilerin çoğunluk oluşturmak istedikleri bölgelere düzenli olarak göç ettiklerinin ortaya çıktığını ve bu durumun dikkatle izlenerek her gün kaç Ermeninin nereye ve ne gibi nedenlerle göç ettiklerinin özel olarak araştırılıp istatistiklerinin düzenli olarak Nezarete bildirilmesinin mecburi olduğunu bildirmektedir.

\footnotetext{
${ }^{25}$ A.g.e., s.20.

${ }^{26}$ E.Brémond, La Cilicie en 1919-1920, Imprimerie Nationale, Paris 1921, s.11-12.

27 Selahattin Tansel, Mondros'tan Mudanya'ya Kadar, 1. Cilt, Milli Eğitim Bakanlığı Yayınları, Ankara, 1977, s. 219.
} 
Ermeni göçleriyle ilgili olarak Harbiye Nezareti'nin elde ettiği ve bu karara gerekçe oluşturduğu anlaşılan yazı ekinde sunulan istihbarat şöyledir;

"Adana'da bulunan itilaf devletleri temsilcileri tarafindan ortaklaşa verilen karara göre, Ermenileri toplamak için emir verildi. Bu konu için Fransız Hükümeti Adana'da bulunan Ermeni Patrik Vekili'ne de bazı emirler vermiştir. Verilen emre göre, Maraş'tan Sivas'a kadar her nerede Ermeni muhacirleri varsa Adana'ya gönderilecek ve bunun alanı Tokat, Amasya, Kayseri, Yozgat, Ankara, Konya, Ereğli, Karaman, Afyonkarahisar, Eskişehir, İzmir ve civarı olan mahallerde bulunan muhacirlerin Adana'ya gönderilmesi ve her gün kaç kişi gönderilecek ise isimleri ile gönderildikleri tarihin İngiliz Komutanlı ̆̆ $ı$ 'na bildirilmesi istenmiştir..." ${ }^{28}$.

Maraş, Antep ve Urfa'daki Fransız kuvvetlerinin komutanlığına getirilen General Querette'in 13 Aralık 1919 tarihli beyannamesinde, Kilikya ve diğer güney illerinin, Padişahla Fransızların uzlaşması üzerine işgal edildiği belirtilmektedir. Beyannamede, bu bölgedeki tüm halkın Fransız silahlarının himayesi altında olduğu da ilan edilmekte ve bu durum, Pozantı'dan Maden yönüne bir de yol yapmaya başladıklarından Kayseri'ye silah sevkini de tasarladıklarını göstermektedir. Kayseri işgal edilirse Türk kolordularını birbirinden ayırmış olacak ve böylece Türkiye'nin paylaşımı üzerine 1916'da yapılan İngiliz-Fransız anlaşması uygulamaya girmiş olacaktı $^{29}$. İşte böylece Fransızlar sözlerinde durmadıkları gibi hareket alanlarını da genişletme düşüncesindeydiler.

Mustafa Kemal, Refet Bey'e gönderdiği 31 Mart 1920 tarihli telgrafta Kilikya'daki durumu özetle şöyle değerlendirmektedir;

“Adana'nın durumu günden güne kötüleşiyor...Kozan çevresinde Müslüman halktan toplanan silahlar ve hayvanlar saldırgan Ermenilere veriliyor. Kozan çevresindeki Hamam, Kurtoğlu Çiftliği, Çolak Hasan, Yassıçall, Mehmet Ağa ve Kabasakal köyleri Ermeni jandarma ve gönüllülerince tümüyle yakılmıştır. Bu köylerden kaçarak kurtulan halktan 750 kişi Ceyhan ve 1500 kişi Karsantı dolaylarına göçmüşlerdir. Bucak yakınlarında birkaç köyün daha yakıldı̆̆ı da haber alınmıştır. Yaşları elverişli Ermenilerin silahlandırılmasına karşın bir tek Müslüman jandarma yapılmıyor. Özellikle Kozan çevresinde Fransız Binbaşısı Taillardat'nın yaptırdığı ve yapılmasına göz yumduğu acıklı olayların anlatılması olanaksızdır... Kilikya'da ve çevresindeki işgal bölgelerinde Fransızların yarattığ durum, Türkler ve Ermeniler arasında karşıllılı olarak bir öç alma duygusunu beslemek ve bunun sonucunda da işgalin kaldırılmasıyla birlikte yerli

\footnotetext{
${ }^{28}$ Askeri Tarih Belgeleri Dergisi, sayı:103, Ocak 1997, s.56; belge no.2874.

${ }^{29} \mathrm{Bkz}$. Tansel, a.g.e., Cilt II, ss.216-220.
} 
halkın birbirlerini boğazlayacaklarını dünyaya yayarak amaçlarına varmaktı" ${ }^{30}$.

Kadirli Grup Kumandanı Tevfik Coşkun'un ${ }^{31}$ hatıralarında anlattıklarına göre de, Fransızlar, Kadirli'de Çerkezleri kazanmaya, Ermenileri de kuvvet olarak kullanmaya çalışıyorlardı. Bu onların işgal politikasının önemli bir özelliğiydi. Nitekim Mart 1920'de Fransızların, Andırın'a karşı Kadirli doğusunda yapmış olduğu tahkimatta Çerkez çeteleri, Ermeni gönüllüleri ve biraz Fransız kuvveti vardı ${ }^{32}$.

Mustafa Kemal'in 9 Mart 1920 tarihli şifreli yazısında, ilgili komutanlıklara ve yerlere, Fransız işgal bölgesinde meydana gelen duruma göre hareket ve ulusal örgütlerin nasıl yönetilmesi gerektiği açıklanmaktaydı. Buna göre; Kozan, Haçın, Feke gibi bölgelerde ortaya çıkmış olan Ermeni acımasızlığının bir an önce söndürülmesi gerekmektedir. Yalnız bu sırada, her türlü Müslüman hareketi Ermeni kırımı şeklinde gösterildiğinden, hareketler her açıdan bu gibi yanlış söylenti ve suçlamalara yer bırakmayacak biçimde yönetilmelidir.Fransız birlikleri ile Ermeni çetelerinin saldırganlık ve sataşmalarına uğramayan yerlerde gereksiz çarpışmalara yer verilmemesi ve yalnız bu tür yerlerde, Ulusal müfrezelerin varlığından yararlanılarak kuruluşların ivedilikle oluşmasına çalışılması, işgal bölgesinin ayrım gözetmeksizin bütün bölümlerinde, Kuva-yı Milliye'nin güçlendirilmesi ve gerek görülen yerlerin, dikkat çekmeyecek biçimde korunması gereklidir ${ }^{33}$.

Bölgedeki güçlü direniş karşısında Fransızlar, bir süre sonra anlaşma arayışına girmişlerdir. Beyrut'ta bulunan General Gouroud'un sekreterinin başkanlığında bir heyet, Ankara'ya gelmiş ve 21-22 Mayıs 1920'de Mustafa Kemal ile görüşmüştür. Mustafa Kemal, bu görüşmelerde Fransız kuvvetlerinin Kilikya bölgesinden tümüyle çekilmesini istemiştir. Heyet ise, önce bir ateşkes anlaşması yapılmasını istemiş ve bu öneri Mustafa Kemal tarafından kabul edilmiştir. 20 günlük bir ateşkes imzalanmıştır ${ }^{34}$. Fakat ateşkes süresince taraflar savaş hazırlıkların sürdürmüşler ve Adana bölgesindeki Ermeni ve Fransız baskıları da iyice artmıştır. Ateşkes süresi 20 gün olarak belirlenmiş olmasına rağmen, Fransızlar bu süreye uymayarak Ermenilerle beraber köylere saldırmışlar ve böylece ateşkes bozulmuş, bölgede çatışmalar yoğunlaşmıştır.

\section{Propaganda, Yanıltıcı Haberler Yayma}

Osman Tufan, Fransız işgalindeki bölgede halkın Milli Mücadeleye yöneltilmesinin başlangıçtaki zorluğunu bilmekteydi. Bu zorluğun dişında, işgal güçlerini etkilemeye dönük propaganda da zorunluydu. Bu yolla elde

\footnotetext{
${ }^{30}$ Onar, a.g.e., Cilt.II, s.80; Harp Tarihi Vesikaları Dergisi, sayı.13, belge no.350. 1967.

${ }^{31}$ Tevfik Coşkun, Kadirli Milli Mücadelesi ve Hatıralar, Kadirli Basımevi, Kadirli,

${ }^{32}$ Tufan, a.g.e., ss.79-84

${ }^{33}$ Onar, a.g.e., Cilt II, s.24.

${ }^{34}$ Askeri Tarih Belgeleri Dergisi, say1: 104, Haziran 1997, s.9; belge no: 2900.
} 
edilebilecek başarılar, halkın moralini ve mücadeleyi olumlu etkileyebilecekti. Çünkü kuvvetler çok sınırlıydı. 1Bu nedenle, gerçekte olmadığı halde büyük bir ulusal kuvvetin gelmekte olduğu yönünde yanıltıcı haberler yayılmakta ve ayrıca bunu da Fransızların öğrenmesi sağlanmaktayd $1^{35}$.

Osman Tufan, Andırın'da ulusal örgütü kurmuş ve propaganda yapmaktaydı. Örneğin bu propagandaların etkisiyle Mürfet Karakolu'ndaki Kadirlili Türk jandarmalar, silahlarıyla kaçarak Andırın'dakilere katılmışlardı. Fransızlar, bu olaydan kuşkulanarak Kozan'dan Supy adlı subayın komutasında bir jandarma müfrezesi göndermişler fakat köylülerden aldıkları abartılı haberlerin etkisiyle geri dönmüşlerdi. Kadirli'de de, "Yıldırım, Yeşilordu" propagandası ortaya atılmış ve oldukça yayılmıştı. Osman Tufan'ın, Kadirli'ye bakan dağ ve tepelere propaganda amaçlı yaktırdığı ateşler, buraya sayısız çetelerin yığıldığı izlenimini vermiş ve Yıldırım ve Yeşilorduların gelmekte olduğu söylentisinin güçlenmesine neden olmuştur. Bu propagandaların etkisiyle Kadirli'deki Ermeniler, burayı terk ederek Kozan'a kaçmışlardı. Oysa bu sırada Andırın'daki örgütlenme ikiyüz çeteyi geçmemekteydi. Tevfik Coşkun da anılarında, bu gelişme üzerine telgraf hattını kestirerek Kozan'la haberleşmeyi kestiklerini ve haberleşme yasağı koyduklarını, dolayısıyla Müdafaa-i Hukuk faaliyetinin de açığa vurulduğunu, Kadirli'nin Çukurova'da kurtuluşun müjdecisi olduğunu söylemektedir ${ }^{36}$.

\section{4. İleri Gelenlerin Tavrı}

Kuva-yı Milliye'nin örgütlenmesi hiç de kolay olmamıştır. Osman Tufan, Andırın'da teşkilatı kurduktan sonra Kadirli, Kozan ve Ceyhan gibi önemli merkezlerde ileri gelen kişilerle bağlantı kurmaya çalışmıştır. Başlangıçta, işgalcilerin yarattı̆̆ Tufan, Kadirli Müftüsü Osman Nuri Efendi'nin iyi ve vatanperver biri olmakla birlikte, Fransızların halkı zorla topladığı ve vaaz vermek için kendisini çağırdığı camide "Ulülemre itaat lazımdır, bugün ulülemrimiz, Fransız hükümeti celilesidir. Fransa'ya ve onun kumandanlarına bizim için itaat farzlaşmıştır" şeklindeki hüküm ve fetvasını duyunca müteessir olur ancak çaba göstermekten yılmaz. Bir süre sonra Kadirli Grup Kumandanı Tevfik Coşkun ile Andırın-Kadirli sınırında görüşürler. Genel olarak bakıldığında halkta ve özellikle Kadirli'nin ileri gelenlerinde bir kararsızlık egemendir. Fransızlar mı yoksa Kuva-yı Milliye mi daha güçlüdür ?. Kuvayı Milliye güçlü ve başında tanınmış bir komutan varsa, o zaman çalışmaya heveslenmekteydiler. Özellikle yaşlılar bu düşüncedeydiler. Fakat Kuva-yı Milliye, bildikleri Andırın köylülerinden ibaret ise ve güçlü değilse boş yere Fransızları kızdırmak istemiyorlardı. Fakat gençler böyle düşünmüyorlardı.

\footnotetext{
${ }^{35}$ Tufan, a.g.e., ss.70-71.

${ }^{36}$ Coşkun, a.g.e., 1967, s., 28.
} 
Ancak Kadirli'nin en yaşlı ve alim kişisi sayılan Hazım Efendi'nin ${ }^{37}$ ise, baştan itibaren gençlerden daha da girişimci olduğu anlatılmaktadır.

Hazım Agâh Efendi, bölgenin işgali üzerine General Gouraud'ya yazdığı 5 Nisan 1920 tarihli mektupta şöyle demekteydi;

"General Gouraud cenaplart, Adana vilayetimizde, taht' $t$ tasdikinde bulunan mütareke ahkâmt külliyen ihlal edilmiştir. Mezalim-i idare-i keyfiye, utanç verici bir hal almış olup medeni bildiğımiz eski dostumuz Fransızlara asla layık değildir. Siz merkez vilayete girer girmez, gerek eşhas yedlerinde ve gerek vilayet depolarında bulunan bütün esliha ve hatta en ufak alat-l cerihayı dahi aldınız. Bu gibi muamele ilerde vilayetin asayişine halel gelmemesi için bir idari tedbir ve ihtiyat-l askeri olduğunu zannetmiştik. Maalesef bu tahminimizde hata etmiş olduğumuzu anlamak çok sürmedi. Çünkü bu silahların bizlerden alınması asayişi muhafaza için olmayıp, düşüncemizin hilafında, bu toplanan silahlar Ermenileri teslih ve teşvik içinmiş...Gelelim maksada: Bir seneyi mütecaviz istilay askeriyeniz altında bedbaht olan memleketlerimizde teraküm eden cinayet ve ardı arkası kesilmeyen ve kesilmeyeceği de görülen taht-l idarenizde tahakkuk eden mezalime karşı, bir gün vatanımızı kurtarmak için milletimizin büyük bir azm-ü sebat ile hakk-ı meşruuna sarıldığı görülecektir. Kuva-yı Milliyemizin istinad eylediği kuvvet, hak ve hakikattir. Atisi meçhul kalmayan, tehlikeye karşı ittifakla sebattır. Askeri işgalin altındaki yerlerde Türkleri tedrici bir suretle ifna politikası belirdiğini, efrad-ı milletde görmeyen ve hissetmeyen kalmadı. Bundan sonra ecnebi idaresinde yaşamanın kabil olmayacă̆ dersini aldık ki bu dersi bize öğreten, her günü bir asır kadar uzayıp giden sizin muamelat-l cariyeniz olduğundan, size karşı minnettar olsak sezadır. Hakkımızı talep hukuk-u sarihemizi müdafaadan ibarettir..." 38

Osman Tufan, Fransa'nın işgal ettiği bölgede başlangıçta milli harekete engel olanlara ilişkin bazı bilgiler vermektedir. O'na göre, bunların başında Fransızların güvenini kazanan, Fransızların Kozan Jandarma Komutanı Yüzbaşı Ali Saip ve faaliyetleri gelmektedir. Fakat Ali Saip'in, Kuva-yı Milliye'ye kazanılması için çaba harcandığını ve bunda da başarılı olunduğunu belirtir. Osman Tufan, Ali Saip ile görüşmüş ve Fransız yetkililerin bu görüşmeyi öğrenmesi üzerine, Fransızlar Onu Urfa Jandarma

${ }^{37}$ Ahmet Karamüftüoğlu'nun aktardığı mezar kitabesindeki bilgilere göre, Kars-1 Zülkadriyeli (Kadirli'li) Karamüftü Hazım Efendi, diğer adıyla Hazım Agah, 1847'de doğmuştur. Öğrenimini Kayseri ve İstanbul'da yapmıştır. Ali Suavi ve Padişah V. Murat olayından sonra memleketine dönmüștür. Kozanoğlu isyanına karıșış, çıkan affa uymayıp Irak'a gitmiştir. 22 yıl Reji inhisarında müdürlük ve müfettişlik yapmıştır. Daha sonra memleketine dönmüş ve Meşrutiyet için çalışmıştır. 1928 yılında vefat etmiştir. Bkz. Seviye Solak, Horasan'dan Çukurfenk'e ve Dikirli-Karamüftüoğlu'nun Yarım Kalan Notları, Tas Medrese Yayınları, Erzurum 1999, s.58-59.

${ }^{38}$ Solak, a.g.e., s.69-73. 
Komutanlığı'na tayin etmişlerdir. Osman Tufan'a göre Ali Saip, gizli milli komutanlardan biri olarak büyük yararlıklar göstermiş, Kozan ve çevresinde yaptıklarını affettirmeye çalışmışıı ${ }^{39}$. Ali Saip (Ursavaş) ise, anılarında daha önce de Kuvayı Milliye lehine çalıștığını öne sürmektedir. Bununla ilgili olarak Kozan'da, Ali Şadi (Çelik), Yarımzade Ahmet Efendi, Hüseyin Efendi ve Baytar Müfettişi Muzaffer (Berkman) Bey ile birlikte "İntibah (Uyanış) Cemiyeti" adı altında gizli bir örgüt kurduklarını ve Kuva-yı Milliye teşkilatına memur edilen Osman Tufan Bey ile görüştükten ve anlaşmaya vardıktan sonra aynı gün, Cemiyetin Müdafaa-i Hukuk Cemiyeti adını aldığını belirtmektedir ${ }^{40}$. Ali Saip'in sözünü ettiği bu cemiyetle ilgili başka bilgi bulunmamaktadır.

Kuva-yı Milliye örgütlenmesi, işgal altında bulunan bölgenin, mülki yönetiminin bazı tutumları nedeniyle de sorunlar yaşamaktaydı. Bu duruma Adana Valisi'nin hatalı bir girişimi örnek verilebilir. Şöyle ki, 5 Mart 1920 tarihli ve 12. Kolordu Komutanı Fahrettin Bey'e gönderilen bir telgrafta, Adana Valisi Celal Bey'in istemeyerek ve zorlanarak Dahiliye Nezareti'ne bir telgraf yazmış olduğu ve burada, Maraş ile Adana arasındaki ulusal çetelerin telgraf tellerini bozdukları ve onarmaya giden telgraf çavuşlarını korkuttukları, Adana'da kaygı yarattıkları, bunun sonucunda kötülük çıkacağı, çetelerin buralardan uzaklaştırılması için Maraş Mutasarrıflı̆̆ı'na emir verilmesi gerektiğini bildirdiği belirtildikten sonra, Mustafa Kemal, bu telgrafı ne denli Fransızların zorlamasıyla yazdı̆̆ını söylüyorsa da, bu Valinin, düşmanlarca da kullanılarak başkenti zor durumlara sokmasından ve bu tür durumları resmi yazı ile yazmasının kötü sonuçlar yaratacağını belirtir. Ardından da Kuva-yı Milliye'nin eylemlerinin, yabancılar gözünde kötü anlayışlara neden olacağından, bu prensibin acele bir şekilde Vali Celal Bey'e duyurulması ve yapılan bu önemli yanlışların giderilmesi için çaba harcanmasını istemiştir ${ }^{41}$. Bu durum, işgal altındaki Adana'da valilik yapan Celal Bey'in, zaman zaman durumu kavramakta zorlandığını düşündürmektedir. Belki bu nedenle Kuva-yı Milliye komutanlarının, özellikle bölge ileri gelenlerini davaya kazanma politikası izledikleri görülmektedir.

Osman Tufan, 27 Mart 1920'de "Andırın Milli Teşkilatı" ve 400 dolayında bir kuvvetle Kadirli'ye gelmiştir. Osman Tufan, Tevfik Coşkun'la özel olarak yaptığ 1 görüşmede, o dönemin Kadirli eşrafından Müftü Osman Nuri, Kasım Ünal, Hacı İdem, Menzilet Veli ve Çıldır İbrahim'i Maraş'ta oturmaya mecbur tutmak istediğini belirtmiş, Tevfik Coşkun ise böyle bir muamelenin bir ceza uygulamasıyla davaya zararlı olacağını, bu beș kişi her ne kadar Halifeci iseler de, işgalin korkunçluğunu bizzat görmüş olduklarından ve Padişah/Halifenin yayınladığı beyannamenin işgal

${ }^{39}$ Tufan, a.g.e., s.48

40 Bkz. Ali Saip Ursavaş, Çukurova Faciaları ve Urfa'nın Kurtuluşu, Kastaş A.Ş.Yayınları, istanbul, 1988, ss.25-29.

${ }^{41}$ Harp Tarihi Vesikalarn Dergisi, sayı.18, belge no.467; Onar, a.g.e., Cilt II, s. 18, belge no. 650 . 
kuvvetleri etkisiyle yapılmış olduğunu takdir edebileceklerini ve bunlardan kötülük gelmeyeceğini, hatta ulusal davaya hizmet edeceklerini söylemiştir. Böylece davaya muhalif olabilecekleri düşünülen kişilerin oradan uzaklaştırılmak yerine davaya kazandırılması yoluna gidilmiştir ${ }^{42}$.

Bu kişilerden Müftü Osman Nuri Efendi, gerçekten de burada Kuva-yı Milliye örgütü içinde önemli bir yer edinmiştir. Ona ilişkin elimize geçen belgeler ve bilgiler bunu göstermektedir. Milli Mücadele süresince iaşe, haberleşme ve çetelerin düşmana saldırılarında önemli etkileri olmuştur. ${ }^{43}$

II. Kozan Cephesinde Ulusal Kuvvetlerin Kurulması ile ilgili olarak Tevfik Coşkun anılarında, Kadirli'ye göç etmiş olan Kozanlıların da cemiyet kurmak istediklerini ve Heyetin başına Ali Şadi (Çelik) getirildiyse de, Kozan'daki akraba ve emlakına düşman tarafından zarar gelir düşüncesiyle kabul etmediğini ve bunun üzerine başka bir kişi seçilmiş ise de, daha sonra Zahit Çamurdan'ın Heyet Başkanı olduğunu belirtmektedir. Kadirli'deki Ermenilerin Kozan'a, Kozan'daki Müslümanların da büyük ölçüde Kadirli’ye göçünden sonra Kuva-yı Milliye Kozan'ı Sıraelif ve Kayhan tepelerinden abluka altına alıp zorlamaya başlamışlardır ${ }^{44}$. Sonuçta Kuva-yı Milliye örgütlenmesi bölge ileri gelenlerini de kapsadığı ve toplumda bütünleşme sağlandığı ölçüde başarıya ulaşacaktır.

\section{Köylülerin Rölü}

Köylüler, Kuva-yı Milliye'nin temel insan kaynağıydı. Osman Tufan da, bölge Kuva-yı Milliyesini örgütlemeye köylerden başlamıştı. O, köylüleri yavaş yavaş örgütlemeye başlamış ve Kozan-Hacın yolundan nakledilen cephaneler için pusular kurulmuş ve bu yol, Fransızlar için tehlikeli hale getirilmiştir. Fransız işgalindeki bölgeden kaçarak gelen Türk jandarmalarıyla Osman Tufan'ın emrinde 15-20 kişilik bir kuvvet oluşmuştu. Bu çekirdek kuvvetle teşkilat yapabilecek yani örgütlenilebilecek bir duruma gelmişlerdi. Tufan, Andırın'ı kuzey-güney ve doğu bölgelerine ayırarak, her birine bir komutan, evinde kaldıkları Yaycıoğlu İbrahim Ağa'yı da onların başlarına Grup Komutanı tayin etmiştir. Köylerden askerlik yapmış olanları ve silahı bulunanları toplayıp eğitime başlamışlar ve böylece örgütlenme sürmüştür ${ }^{45}$. Her tarafta Andırın'da bir milli teşkilat kurulduğu duyulmuş, bizzat Osman Tufan'ın kendisinin de ortaya attığ ${ }_{1}$ abartılı haberler, kısa sürede Fransızlar tarafından duyularak böylece Fransızlar tedirgin edilmiştir.

\footnotetext{
${ }^{42}$ Coşkun, a.g.e., s. 29.

${ }^{43}$ Osman Nuri Efendi 1852 'de Kadirli'de doğmuştur. Kayseri ve Maraş medreselerinde eğitim görmüş ve 1892 'de Kadirli Müftüsü olmuştur. 1899'da Kadirli'de bir medrese açmıştır. 1915'de Adana Müftülüğü'ne atanmış, 1916'da ise kendi isteği üzerine tekrar Kadirli Müftülüğü'ne tayin edilmiştir. İğtişaş’ta, Müftü Osman Nuri Efendi'nin çabalarıyla Kadirli'de vahim olaylar yaşanmamıştır. Yatıştırıcı konuşmalarıyla olayların önüne geçmiştir. Olaylardan sonra Adana'da çalışmalara başlayan soruşturma heyetleri, Müftü sayesinde Kadirli hakkında dosya açmamıştır. Müftü'nün dini, siyasi çabaları sonucunda Kozan Sancağı dahilinde de trajik olaylar yaşanmamıştır. Düşman işgali sırasında halkın manevi yapısı üzerinde etkili olmuştur. Bkz. Seviye Solak, a.g.e., ss.120-125.

${ }^{44}$ Coşkun, a.g.e., s.38

${ }^{45}$ Tufan, a.g.e., s.64.
} 


\section{Bölgedeki Derneklerin Rolü}

İstanbul'da kurulan Kilikyalılar Cemiyeti'nin, bölge işgal altında olduğundan önemli bir işlev üstlenemediği anlaşılmaktadır.

Kilikyalılar Cemiyeti, Harbiye Nazırı Cemal Paşa aracılığıyla Mustafa Kemal'e gönderdiği 13.12.1919 tarihli beyannamede, çalışmalarından söz etmekte ve Adana, Maraș, Antep ve Urfa ile son zamanlarda ilişki kurulması ve haberleşmeye imkan bulamadığından olaylardan günü gününe haber alamadıklarını ve bu nedenle görevlerini zamanında yapamadıklarını belirtmektedir. Cemiyet, bundan dolayı milli teşkilat ve o bölge ile ilişki kurma ve günlük olaylar hakkında, kendilerinin de haberdar edilmesi konusunda faaliyete geçilmesini istemektedir. Cemiyetin bu yazısına yine Cemal Paşa aracılığıyla verilen cevapta; Kilikya içerisinde ve çevre bölgelerde teşkilata önem verildiği, Kilikya Kuva-yı Milliye Komutanlığı'nın kurulduğu ve yazışmalar için komutanlar görevlendirildiği bildirilmiştir ${ }^{46}$.

İşgal altındaki Çukurova'da, Müdafai Hukuk Cemiyetlerinin kurulması Kuva-yı Milliye açısından çok önemliydi. Tevfik Coşkun anılarında, işgal döneminde Kadirli'de Müdafaa-i Hukuk Cemiyeti'ni kurmaları konusunda, Sivas Kongresi ve kurulmuş olan Müdafa-i Hukuk Heyeti hakkında gelen haberlerden etkilendiklerini ve aynı adla bir cemiyet kurmak için harekete geçtiklerini, 10 maddelik bir nizamname hazırladığını ve güvenilir kişileri gizli toplantıya çağırdıklarını, kurdukları Cemiyeti, Sivas'ta kurulan Cemiyetin şubesi olarak gördüklerini ${ }^{47}$ belirtmektedir. Bölgede eşraf vs. ileri gelenler, özellikle Mudafai Hukuk heyetlerinde yer almaktaydılar.

\section{Kuva-yı Milliye'nin Ekonomik Altyapısı}

Kuva-yı Milliye'nin ilk kuruluş günlerinde, Ege'de olduğu gibi burada da, mali kaynağa pek ihtiyaç duyulmamış olduğu ve Kuva-yı Milliye bir halk hareketi şeklinde geliştiğine göre, tüm harcamalarının da halk tarafından karşılanmış olduğu söylenebilirr ${ }^{48}$. Çünkü, Çukurova'da Kuva-yı Milliye kurulması konusunda atılan ilk adımlarda, bölgede böyle bir örgütlenmeyi sağlayacak maddi ortamın mevcut olduğu şeklinde bilgiler mevcuttur. Sivas Kongresi'nden sonra Mustafa Kemal ile görüşen Kozan yetkilileri, Adana bölgesi halkının silah ve cephanesinin, Birinci Dünya Savaşı'ndan saklanmış olarak yanlarında bulunduğunu, halkın böyle bir harekatı idareye maddi açıdan durumunun yeterli olduğunu, zahire ambarlarının dolu olduğunu ve Sivas'tan verilecek emirle düşmana saldıracaklarını belirtmişlerdir.

Kuva-yı Milliye'nin, bölgeye yakın ordu birlikleri tarafından güven altına alınması kararlaştırılmış ve kolordulara aşağıdaki talimat verilmişti:

${ }^{46}$ Askeri Tarih Belgeleri Dergisi, sayı: 103, Ocak 1997, s. 98-99; belge no. 2886.

${ }^{47}$ Coşkun, a.g.e., ss. 24-27.

48 Alptekin Müderrisoğlu, Kurtuluş Savaşı'nın Malî Kaynakları, Atatürk Araștırma Merkezi Yayınları, Ankara, 1990, s.183. 
"Her kolordu kendisine verilen bölgeyi daha küçük bölgelere böler, her bölge için en yakın yerlerde birer idare merkezi kurar. Bu merkezler, teşkilatta görev alacakların ikmal yeri, gönderilecek silah, cephane ve diğer malzemenin depo yeri ve muhabere merkezi olur. Bu kuruluş çok gizli tutulur...

Vilayet, sancak ve ilçe merkezlerinde birer "Idare Heyeti" kurulmalıdır. Bu idare heyetlerinin başlıca görevi halkı uyandırmak ve varlı̆̆ını devam ettirmek, yolsuzluklara meydan vermemek şartıyla halktan yardım toplamak ve bu yardımlar gereken yerlerde kullanmak ve dağıtmaktan ibarettir.

...Görevliler Kolordu ve Tümen Komutanlarının ve Heyet Merkezlerinin belgesini taşımalıdırlar. Bunlara görevlerinde yiyeceklerini sağlayacak kadar aylık verilmelidir. Teşkil edilecek yerli ve gezici gönüllü müfreze komutanlarına, rütbeleri ne olursa olsun ayda, hayvan yiyecek parasindan başka, 30 lira verilecektir. Bu müfrezelerin erlerine günde yarım lira ve bir çift ekmek verilecektir..." 49

Bölge'de Kuva-yı Milliye, işgal edilen yerlerin sınırında kurulmaya başlanmış ve işgal altındaki yerlerde de örgütlenme sürdürülmüştür.

İdare Heyetleri, görünürde farklı adlarla da olsa gerçekte "Müdafa-i Hukuk Cemiyeti” olarak faaliyet göstermekteydi. 1919 yılı sonlarında çabalar artırılmıştır. Bir yandan cemiyet üyeleri çoğalırken bir yandan da Kuva-yı Milliye için para, silah ve cephane sağlanmaya çalışılmaktaydı. Cemiyete giren her üye, durumuna göre, bir silah sağlamakla yükümlüydü. Müderrisoğlu'nun belirttiğine göre, ayrıca durumu uygun olanlardan para da alınıyordu. Ancak Çukurova'da her zaman böyle olmadığını düşündüren bilgiler bulunmaktadır.

Osman Tufan, Kadirli'de önce bir Müdafaa-i Hukuk Heyeti seçtirmişti. Burada teşkilat, tıpkı Andırın'daki gibi örgütlenmişti. Osman Tufan'a göre, iaşe konusunda sorun çıkmamıştır. Ulusal harekât süresince, kimse aç kalmadığı gibi halktan da olumsuz tepki görülmemiştir. Kimseden para alınmamakta, Müdafaa-i Hukuk sandığında bazı ihtiyaçlar için bulundurulacak para ise, ganimet mallarının müzayedeyle satılmasıyla sağlanmaktaydi ${ }^{50}$.

Fakat Andırın kuvvetleri de geldikten sonra en önemli sorun iaşe işi olmuştu. ${ }^{51}$ İaşe işlerinin günden güne önem kazanması üzerine, vergi niteliğinde bazı yükümlülükler konulması ihtiyacı belirmiştir. Bu nedenle, bu işlerle uğraşacak bir heyete gerek duyulmuş ve Müftü Osman Nuri Efendi başkanlığında bir İaşe Heyet'i kurulmuştur.

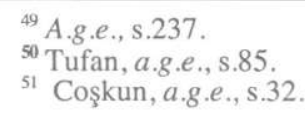


İaşe Heyeti kurulduktan sonra, yüzde hesabıyla zahire ve küçükbaş hayvanlardan vergi alınmaya başlanmış ve böylece iașe işleri biraz daha rahatlamıștır ${ }^{52}$.

Osman Tufan, bölgedeki Kuva-yı Milliye'nin faaliyetlerini etkileyen bir diğer önemli faktöre dikkat çekmektedir. O da yaylacılıktır. Şöyle ki, iaşe kaynağını büyük ölçüde Aydınlı Așireti ve Çukurova köyleri oluşturduğundan, Nisan ayı geldiğinde bunlar, mutlaka yaylaya çıkmaları gerektiğini yoksa hayvanlarının ovada mahvolacağını ileri sürmekteydiler. Bunlar giderse iskan, iaşe kaynağı ve bunların silah gücü elden çıkacağından, bir tür erken terhis söz konusu olacaktı. Kozan kuşatmasında Ermenilerin bunu bekledikleri anlaşılmaktaydı. Osman Tufan, bu yayla mücadelesinin kendilerini çok yorduğunu belirtmektedir ${ }^{53}$.

Kuva-yı Milliye birliklerinin, iaşe dışında silah ve cephane sıkıntısı çektikleri de bilinmektedir. Çünkü işgal güçleri daha donanımlı olup, tayyare ve top gibi gelişmiş silahlara sahipti. Örneğin, Kozan cephesinde de en önemli gereksinim silah ve cephaneydi. Haçın kușatması nedeniyle ordunun sağladığı silah ve cephane, en şiddetli çatışmaların olduğu Haçın cephesinde tutuluyordu. Bu nedenle başka yerlerden silah ve cephane sağlanmaya çalışılmıştır ${ }^{54}$.

Müderrisoğlu'na göre, Kuva-yı Milliye birlikleri, yakınlarındaki kolordu ve tümenlerden destek görmüs ve birçok ihtiyaçları bu düzenli ordu birliklerinden sağlanmıștır ${ }^{55}$. Ancak bunun sürekli ve yeterli olmadığı anlaşılmaktadır. Kilikya Batı Bölgesi Komutanı Tekelioğlu Sinan Bey, 11.Tümen Komutanına gönderdiği 4 Nisan 1920 tarihli raporunda, en büyük sıkıntının silah ve cephane olduğunu belirtmektedir ${ }^{56}$. Bu sıkıntıların bölge çapında devam ettiği anlaşılmaktadır. Çünkü silah ve cephane sıkıntısı, genel olarak Milli Mücadele'nin en önemli sorunlarının başında gelmekteydi.

Selahattin Adil Paşa'nın 2.Kolordu Komutanı olarak bölgeye gelmesi, Kuva-yı Milliye'nin yapılanmasıyla ilgili olarak bazı değişiklikleri gündeme getirmiş görünmektedir. Kadirli Müdafaa-i Hukuk Başkan Vekili Hasan Tahsin, 1 Eylül 1920'de, yeni Kaymakam Talat Bey'in gelişi, Kuva-yı Milliye'nin ve düşmanın durumuna ilişkin olarak Cemiyet Başkanı Müftü Osman Nuri Efendi'ye gönderdiği yazıda, diğer sorunların yanı sıra iaşe konusuna da tekrar değinmektedir:

${ }^{52}$ Coşkun, a.g.e., s.36; Kuva-yı Milliye'nin ihtiyacı olan maddeleri satın almak için gerekli para liste düzenlemek yoluyla halktan toplanmaktaydı.

${ }_{53}$ Tufan, a.g.e., s.86.

54 Kemal Celik. Milli Mücadele'de Adana ve Havalisi (1918-1922), İstanbul Üniversitesi Sosyal Bilimler Enstitüsü Türkiye Cumhuriyeti anabilim Dalı, Doktora Tezi, İstanbul, 1993, s.170; Ahmet Cevdet Çamurdan, Kurtuluş Savașı'nda Doğu Kilikya Olayları, Adana, 1969, s.331.

55 Müderrisoğlu, a.g.e., s.238.

${ }^{56}$ Hulki Saral-Tosun Saral, Vatan Nasıl Kurtarıldı, İş Bankası Yayınları, Ankara, 1970 , s.63; Müderrisoğlu, a.g.e., s.239. 
"Bundan sonra nöbet-i taarruz bizim tarafa teveccüh ettiğinden Osmaniye'ye taarruz hazırlığında bulunulmaktadır. Kars'ta gerek iaşe ve gerek dĭ̆er mesail-i mühimme karşısında pek müşkil bir hal karşısında kaldık. Bu gibi umur-u mühimmeyi hal ve fasletmek için irşadat-l fazılanenize ihtiyacımız derkardır efendim " ${ }^{57}$ demektedir.

\section{Kuva-yı Milliyenin Askeri Yapısı \\ a) Çetecilik}

Çukurova'da Kuva-yı milliye'nin kurulması doğrultusunda Sivas'da alınan karara uygun olarak Develi'de yapılan çalışmalardan sonra, Osman Tufan'ın, yanındakilerle kar, soğuk ve güvensizliğin hüküm sürdüğü zor bir yolculuktan sonra Develi-Göksun-Geban köyü üzerinden Andırın'a ulaşması, Çukurova'da ulusal kuvvetlerin oluşturulması açısından önemli bir başarı olmuştur. Andırın'ın coğrafi konumu ve halkın durumu, Kuva-yı Milliye Teşkilatının kurulması için çok elverişliydi. Çünkü Fransızlar burayı fiilen işgal edememişler ve buradan korunmak düşüncesiyle doğu ve güney taraflarına karakollar kurmuşlard ${ }^{58}$.

Çukurova'da mevcut çetecilik faliyetleri çok eski zamanlara kadar uzanmaktadır. Milli Mücadele döneminde Kuva-yı Milliye'nin oluşumu sürecinde de, bu mevcut çetelerin Kuva-yı Milliye'ye kazandırılanları olduğu gibi, köylerden toplanan silahlılar da "çete" adı altında örgütlenmişlerdir. Bu nedenle geleneksel Çete ${ }^{59}$ olgusu, burada Kuva-y1 Milliye'nin başlangıçtaki temelini oluşturmuştur. Osman Tufan, örgütlenme çalışmaları sürecinde 14 kadar silahlı adamı olan Gizik Duran çetesinden amaçları doğrultusunda yararlandıklarını belirtmektedir. Develi'den Andırın'a doğru yola çıktıklarında yanlarında Hulusi Kurtoğlu ve Gizik Duran'ın 4 arkadaşı vardır ${ }^{60}$. Fransız işgal alanına girilmesi kararından sonra Osman Tufan, Kilikya Doğu Bölgesi Komutanı olarak, Sinan Tekelioğlu da (Yüzbaşı Ratip) Kilikya Batı Bölgesi Komutanı olarak görevlendirilmişti.

Kadirli'nin kurtuluşu üzerine burada örgütlenme sürmüş ve köylerde gizlenen silahlılar, çete adı altında Kadirli'de toplanmaya başlamışlardı. Müdafaa-i Hukuk Cemiyeti de, bunların iaşelerinin sağlanmasını üstlenmişti.

Osman Tufan, 27 Mart 1920'de "Andırın Milli Teşkilatı" ve 400 dolayında bir kuvvetle Kadirli’ye gelmiştir. Rüştiye Okulu karargah

${ }^{57}$ Abdullah Karamüftüoğlu Ailesi'nden Cezmi Yurtsever tarafından alınan belgeler; Tayyıpoğulları Dosyası.

${ }_{58}$ Tufan. a.g.e., s.59.

${ }^{59}$ Çukurova ve çevresinde (Dörtyol, Kahramanmaraş vs.) kurtuluş günleri halk tarafından "Çete Bayramı" olarak anılmakta ve kutlanmaktadır.

${ }_{60}$ Tufan, a.g.e., s.50; Osman Tufan'a göre, Gizik Duran Çetesi, Fransız işgal alanına giremeyip Develi bölgesindeki köyler civarında faaliyet gösterip köylüler tarafından Fransız ve Ermenilere karşı silahlı bir muhafız olarak görülüyordu. Bu arada, bir Ermeni subayını pusuya düşürüp öldüren dört Türk köylüsünün aile ve köylerine zulüm eden Ali Saip'ten intikam almayı düşündüklerinden, Ali Saip'i korkutmak için bu çeteden yararlanılmak istenmiş ve çeteyle bağlantı kurulmuştur. 
yapılmış, çeteler de han ve otellere yerleştirilmiştir ${ }^{61}$. Sayısı 60 kadar olan çeteler, Çukurova'nın kilit noktalarından olan Mercin'de düşmanla şiddetli bir çatışmaya girişmiş ve burada önemli bir zafer kazanmıştır. Fransızlar kayıp vererek Ceyhan'a çekilmek zorunda kalmıştır. Buradaki direniş, Kadirli'nin tekrar elden çıkmasını da engellemiştir. İşgal altındaki Kozan, Ceyhan ve Osmaniye'den bir çok kişi, Kadirli'ye iltica etmiş ve şehrin nüfusu artmış olduğundan, Müdafaa-i Hukuk Teşkilatı bunlara da yardımcı olmaktaydı. Tufan Bey, bir yandan cepheyi idare ederken bir yandan da, Kuva-yı Milliye'ye katılarak cepheye gitmiş olanların eğer çalışabilecek kimsesi yoksa, ziraatinin yüzüstü kalmaması için önlemler almaya çalışmaktaydı ${ }^{62}$.

\section{b) Müfreze ve Bölük Sistemine Geçiş}

Fransızlar, Kadirli'ye yönelik saldırılarını sürdürürken, Kuva-yı Milliye'nin örgütlenmesi konusunda da çalışmalar devam etmekteydi. Tevfik Coşkun bu konuda şöyle demektedir: "Silahlı kuvvetlerimiz bir dereceye kadar teşkilatlıydı. Tatarlı, Bozdoğan, Dağkolu, Sumbas ve Çokak namlarıyla ayrı ayrı silahlanmışlardı. Osman Tufan geldikten sonra bunlara bölük adı verilip öyle anıldı ve bölük teşkilatı yapıldı. Daha sonra da kasabalardan Kasaba Bölüğü adıyla bir bölük daha kuruldu. Yedek subaylardan bir kısmı bölük kumandanı, bir kısmı da askeri müşavir olarak askerlik görmemiş olan bölük kumandanları refakatine verildiler.

Bu bölüklerin dışında Ali Kahyalar, Mamuk Ağa ve Savrun müfrezeleri vardı. Bu müfrezeler 30-50 kişiden oluşuyordu. Bölüklerin mevcuduysa 100150 kişi arasındayd ${ }^{63}$.

Osman Tufan, Remzi Özdemir'i Grup Kumandanı Yardımcısı tayin etmiş, Grup Kumandanlığı ise kendi üzerinde kalmış ve bir süre sonra da Tevfik Coşkun'u Kadirli Grup Kumandanlığı'na tayin etmiştir. Aynı şekilde Yaycıoğlu, Andırın; Kurtoğlu, Kozan; Cevdet Çamurdan da Sırkıntı Grup Kumandanı olarak tayin edilmişti. Haçın alındıktan sonra da, Saim Bey, Ceyhan Grup Kumandanlığına, Nuri Çavuş da yardımcılığına tayin edilmiştir. Böylece Tevfik Coşkun'un anlatımıyla, "Çetecilik" bu suretle disiplin altına alınmış oluyordu. Çetelerin çoğu askerlik görmüş olduklarından grupta çabucak askeri düzen kurulmuş̧u", ${ }^{4}$.

Osman Tufan, Kuva-yı Milliye'nin Kozan çevresinde çeşitli cepheler halinde örgütlenmesini sağlamıştır. Kuva-yı Milliye'nin kurulması görevi,

\footnotetext{
${ }^{61}$ Coşkun, a.g.e., s.29.

${ }^{62}$ Abdullah Karamüftüoğlu Ailesi'nden Cezmi Yurtsever tarafından alınan belgeler; aynı dosya. Bu konuda şu mektup ilginçtir; "Kars Müdafa-i Hukuk Cemiyeti Riyaseti Fazılanelerine, ihtiyar mücahidimiz Salih Ağa mahdumlarının Andırınlılarla Haruniye cephesine hareket etmiş olduklarını söyleyerek ziraatının adamsızlıktan yüzüstü kalmış olduğunu ifade ediyor. Umum mücahitler hakkında Müdafa-i Hukuk Cemiyeti'nin tertip eyledikleri muavenet heyetleri tarafından Salih Ağa'nın işlerinin dahi gördürülmesine istirham eylerim efendim. Kilikya Şark Kuvayi Milliye Kumandanı Tufan"

${ }^{63}$ Coşkun, a.g.e., ss. 32-34.

${ }^{64}$ Coşkun, a.g.e., s.35.
} 
Sırkıntılar Grup Kumandanı Müftüzade Ahmet Cevdet (Çamurdan)a verilmişti. İşgal altındaki Kozan, dört bir yanından kurulan cephelerle kuşatılmıştı.

Kuzeyde, Kargapazarı savaşının kahramanlarından Ali Kahyazade Deli Hacı Başkanlığında, Sıraelif ve Ağlıboğaz dağlarında ilk cephe kurulmuştu. Buradaki Kuva-yı Milliye'yi; Karabucak, Çulluuşağı, Çamdere, Gedikli, Orçan, Çürüklü, Minnetli ve Şerifli köyleri ile çevre dağ köylerinden gelenler oluşturmaktaydı.

Doğuda, Köreken denilen yerde Bayatoğlu Ahmet Çavuş, 30-40 kişilik bir müfreze kurmuş̧tu. Döşeme dağı denen yerde ise, Yiğit Ağa, Boztahta, Akçalıuşă̆ı, Karahamzalı ve çevre yerlerden 70-80 kişilik bir müfreze kurulmuştu. Köreken dağının güneyinde yeralan Kuyuluk ve Buzluklu köylüleri de Üzeyir Efendioğlu Hasan'ın (Akçalı) komutasında “Kuyuluk Bölüğü" adıyla 50-60 kişilik bir müfreze oluşturmuştu. Yapılan hazırlıklarla 2-3 Nisan 1920'de Köreken dağlarında Kozan Doğu Cephesi kurulmuştur.

Batıda ise, Nisan 1920 başlarında önemli bir örgütlenme olmamakla birlikte Tahsildar Hakverdizade Hakkı Efendi, 70-80 kişilik bir kuvvet oluşturmuştu. Kurtoğlu Hulusi Efendi ise Kozanlıların sığındığı Ceritler köyünde, Topaloğlu Halil, Yeğenzade Ahmet ve Karaçalı'dan birtakım gençlerle bir müfreze kurmuştur. Bu müfrezeye daha sonra katılanlar olmuş ve müfrezeye "Aslanlı Bölügüü" adı verilmiştir. Aslanlı Bölüğü, Fransızların Kozan'ı boşaltmasından sonra Komutanı Kurtoğlu Hulusi ve Kozan Grubu ile birlikte Osman Tufan Bey'in Mercimek ve Isırganlı karargahlarında da görev yapmışlardır. Kuva-yı Milliye'nin örgütlenmesi açısından önemli diğer bir gelişme de, Yukarı Sırkıntı nahiyesinde ulusal örgütün kurulması ve Sırkıntı Grup Kumandanı Ahmet Cevdet (Çamurdan) ile Sarıbahçeli Ahmet Ağa ve 35 kişilik müfrezesiyle buraya gelen Avcı Mehmet Ağa'nın yaklaşı 100 kişilik Yukarı Sırkıntı Bölüğünü kurmaları olmuştur. Konak köyünden Samur Ağa'nın oğlu Çerkez Bey, Bölük Kumandanı olmuştur. Aynı şekilde Aşağı Sırkıntı'da da Çinçikoğlu Mehmet Ali Efendi komutasında bir bölük kurulmuştur. Saygeçit Müfrezeleri adı verilen bu iki bölügün Kumandanı Ahmet Cevdet(Çamurdan) idi. Sarıbahçeli Ahmet Ağa Başdanışman, Avcı Mehmet Ağa da Kumandanın yanında bulunacaktı.

Güneyde, Kuva-yı Milliye'nin kurulması işi, Tufan Bey tarafından, Andırın'dan yanında gelmiş olan ve Çukurköprü Mıntıka Kumandanı tayin etmiş olduğu Yaycıoğlu Ali Ağa'ya verilmişti. Ali Ağa'nın çabalarıyla, Çukurköprü'de çeşitli köylülerin oluşturduğu "Hamam Köyü Bölüğü" adlı müfreze kurulmuştur. Müfreze Kumandanı Bayram oğlu Hacı Mehmet Ağa'dır. Güney'deki diğer bir müfreze de, 20-30 kişilik Çolak Hasanoğlu Hac1 Sözdoğuran Müfrezesi olup bu müfreze, "Seyyar Süvari Bölügüü" adiyla da anılmaktadır ${ }^{65}$.

${ }^{65}$ Çelik, a.g.t, ss.166-170. 
Kozan çavresinde kurulan tüm bu müfrezeler, Aydınoğlu (Osman)Tufan Bey'e bağlıydı. Sayıca 10-12 kadar olan bu müfrezelerin toplam mevcudu 800-900 kişi civarındaydı. Bu kuvvetler dışında başka destek kuvvetler yoktu. Andırın ve Kadirli grupları, sürekli olarak Kadirli Karargahı'nda bulunuyordu. Tufan Bey, bu müfrezelerden zayıf gördüğü cepheye gerektiği zaman destek kuvvet göndermekteydi. Osmaniye ve Ceyhan tarafında düşman, kuvvet gönderebileceğinden Kadirli güneyi ve doğusu tehlikeye açıktı. Bu nedenle Kozan cephesine Kadirli'den fazla kuvvet aktarilamiyordu ${ }^{66}$.

Haçın, Kemal Doğan tarafından kuşatılmıştı. İyi tahkim edilmiş olan bu yerin ele geçirilmesi sekiz ay gibi uzun bir süre almıştır. Osman Tufan, 25 Eylül 1920 tarihli bir yazıyla, Haçın kuşatmasıyla ilgili olarak Kadirli Müdafaa-i Hukuk Heyeti'ne bilgi ve gerekli kuvvetlerin toplanarak gönderilmesi için direktifler vermekteydi ${ }^{67}$.

Selahattin Adil Paşa'nın 2. Kolordu Komutanı olarak bölgeye gelmesi, Kuva-yı Milliye'nin yapılanmasıyla ilgili olarak bazı değişiklikleri gündeme getirmiş görünmektedir. Kadirli Müdafaa-i Hukuk Başkan Vekili Hasan Tahsin, 1 Eylül 1920 tarihli ve yeni Kaymakam Talat Bey'in gelişi, Ulusal kuvvetlerin ve düşmanın durumuna ilişkin olarak Cemiyet Başkanı Müftü Osman Nuri Efendi’ye yazdığı mektupta;

“...Tufan Bey'e olan mektubunuza cevaben müşartnileyhten alinan telgraf aynen takdim olunuyor. Usul tebeddül etti. Vaziyet mühimdi. Kozan Sancă̆ı Mintıka Kumandanlı̆̆ına Kaymakam Talat Bey tayin kulınmış. 26 Ağustos 1336 (1920) tarihinde Kars'a muvasalatla ertesi günü alessabah Kozan'a azimet buyurdu. Maiyetinde ü̧̈ zabit vardır. Birisi istihkam zabiti olup Hactn mürettebatlarından olduğu ve doğruca Hacın'a gideceği haber alındı.Kumandan müşarınileyhin takib edeceğg hattı hareket tabii henüz malum olmadığından Tufan Bey'in telgraf mündericatı hakkında bir şey söylenemiyeceği ve yapılamıyacağı bir emr-i tabiidir" ${ }^{68}$ sözleri bu konuda bazı ipuçları vermektedir.

\section{c) Örgütlenme Sorunlart}

Kadirli Grup Kumandanı Tevfik Coşkun, Kadirli Müdafaa-i Hukuk Heyeti'ne gönderdiği 23/24.9.1920 tarihli raporda, Selahattin Adil Bey'in cepheyi teftişi, Kuva-yı Milliye'nin ve düşmanın durumunu ve

${ }^{66}$ Çelik, a.g.t., s.170; Çamurdan, a.g.e., s.331.

${ }^{67}$ Abdullah Karamüftüoğlu Ailesi'nden....aynı dosya;

"Kars Heyet-i idaresine, inayet-i hakla Haçın'a son ve kat'i darbeyi vurmak üzere bugün hareket ediyorum. Milletin vaadi üzerine size müracaat ediyorum. Kars'ta ne kadar perakende efrad varsa muhtelif kollara mutemed memurlar çıkararak süratle Sunbas, Savrun, Çokak kuvvetlerinin cem' edilmesi ve doğruca Haçın'da emrime intizar eylemeleri hususunun temini ehemmiyetle istirham olunur, efendim. 25 Eylül 1920 Kuvayi Milliye Kumandanı Tufan".

${ }^{68^{\circ}}$ Abdullah Karamüftüoğlu Ailesi'nden....aynı dosya. 
faaliyetlerini ${ }^{69}$ açılamaktadır. Tevfik Coşkun'un gönderdiği başka bir rapor, cepheyle ilgili bir durum değerlendirmesi olduğu kadar, Kuva-yı Milliye'nin Osmaniye ve çevresinde iyi örgütlenmemiş olduğu ve düşmanın harekatında önemli bir direnişle karşılaşmadığı, Ulusal Kuvvetlerin iaşe sorunları ve dağılan bölüklerin takviye edilmesi, cephe disiplini açısından Tufan Bey'in buraya gelmesinin yararlı olacağı konusunda önemli bilgiler vermektedir. Rapor şöyledir;

"Kars Heyet-i idaresi Riyaseti Fazllanesine,

1. Dün gurub vakti Arabli'ya muvasalat ettik. Burada bulunan müfrezemizden başka karşılayan olmadl. Mamafif bura heyetinde bunu takdir edecek bir kafa göremedim.

2.Düşman Mustafabeyli, Toprakkale ve Osmaniye arasında toplanmıştır. Maksadının Adana'ya geçmek olduğu anlaşılıyor. Fakat büyük topun muavenetiyle İbrahim Bey biraz hail olabiliyormuş. Bir iki defa düşmanın geçmek teşebbüsü akim bırakılmıştır. Osmaniye'de henüz kuvveti vardır. Bu gece müthiş müsademe oldu. Bomba gürültüleri gece yarısina kadar devam etti.

3.Yürük Selim (Sinan Paşa) ve Kılıç Ali Beylerin bini mütecaviz kuvvetleri kısmen Osmaniye'de, kısmen de Çardak'ta bulunuyor. Osmaniye Kuvayi Milliyesi ismi var cismi yok kabilinden bir halde imiş. Bütün cephe gayet hafif kuvvetlerle bekleniyormuş, teşkilat olmadı̆̆ için ikisi gelirse beşi gidiyormuş.

4.Yarım saatten beri Osmaniye'ye karşı Selim Bey tarafindan fasilalt top endaht ediyor.

5. Arslan Bey, bu akşam Arablı'da idi. Fakat görüşemedim. Sabahleyin Osmaniye'ye gitmiş. Maraş'a avdet edecĕ̆ini söylüyormus.

6. Düşman İslahiye'den buraya kadar harekatında hiç bir taraftan ehemmiyetli tazyike maruz kalmamıs. Duyduklarımız mübalăgadan ibaretmiş.

7. Düşmanın Erzin tarafına geçmesi ihtimali dolayısıyla Kısık yolunun Ermeniler tarafindan tutulduğu söyleniyor.

8. Bizim Bozdoğan Bölüğü dă̆ılmıştır. Dün Hacı Bey yirmi nefer bizden önce buraya göndermiştir. Hacı Bey'e yazdım. Zat-l aliniz de behemehal kuvvet toplayıp bir iki güne kadar iltihakını temin buyurunuz.

9. İaşe ve Heyet-i Merkeziye'nin işi pek bozuk. Daha doğrusu umum Osmaniye ahvali karışık. Vaziyete hakim bir adam olmadı̆̆ gibi umumi kumanda verecek bir zat da yok. Tufan Bey'in herhalde

${ }^{69}$ Abdullah Karamüftüoğlu Ailesi'nden...aynı dosya. 
buraya teşrifi fevkalade elzemdir. Zira zavallt ve aciz Heyet-i Merkeziye elde oyuncak gibi.

Mutasarrıf da aciz ve lakayt bir adam. Lakırdl söylemeye bile kudreti yok, adeta yaratılışta hasta. Bizim Nuri Çavuş ${ }^{70}$ buranın en zeki ve işgüzar bir adamı olmuş. Mamafih o da gelmese imiş bu zavallılar tamamıyla şaşırıp kalacaklarmıs.

10. Bu sabah Selim Bey'e posta gönderdim. Kendi kendimize hareket tabii muvafik olmıyacă̆ından mümaileyhten vazife tayin edilmesini sorduk. Osmaniyelilerin söylediğine bakllırsa bu zat da pek lakayt. Bu işi adeta vazife edinmiyormuş. Herhalde Osmaniyelilerce sevilmemiş. Belki de Osmaniyeliler onu takdir edemiyor. İhtiram efendim. Coşkun"7l.

2 Haziran 1920'de Fransızların boşalttığı Kozan'a girilmiştir. Osman Tufan'nın verdiği bilgiye göre, Kuva-yı Milliye güçleri çok yorulmuş ve köylerde çiftler yüzüstü kalmıştı. Dinlenmeye ihtiyaçları vardı. Kozan alındıktan sonra, halkta eski gayrette bir gevşeme de görülmekteydi. Kuva-yı Milliye'de çalışan halk, daha güneye gitmek, Adana'yı zorlamak konusunda kendi bölgelerine uzak olduğundan pek istekli görünmüyorlardı. Yine Osman Tufan'ın açıklamalarına göre, esasen Teşkilat bölgeye bağlıydı. Kuvvetler azalmıştı ${ }^{72}$. Bütün bunlar, Çukurova'da, Kuva-yı Milliye'nin bölgenin yaşam koşullarından da kaynaklanan nedenler yanında, özellikle bu örgütlenmenin hemen tümüyle, sivil halkın organizasyonuna dayanması ve çok sınırlı sayıda asker bulunmasından dolayı birtakım örgütlenme sorunları yaşandığını göstermektedir.

\section{d) Ulusal Kuvvetler (Kuva-yı Milliye)'in Lă̆vı ve Düzenli Ordu Sistemine Geçiş}

Diğer yerlerde olduğu gibi bu bölgede de düzenli ordu teşkilatı kurulması kararlaştırılmıştı. Tevfik Coşkun, bu kararın uygulanmasıyla ilgili olarak, "10 aydan fazla devam eden müsbet sonuçlara ulaşan mücadelemiz sona ermiş, yedek subay olarak silah altına çağrılmıştık. 25 yedek subay Kozan'da Yarbay Talat Bey'in emrinde toplandık." demektedir.

Osman Tufan ise anılarında, "Milli Kuvvetlerimizde İnhilal Başlangıcı" başlıklı bölümde, Kuva-yı Milliye'nin durumuyla ilgili yaptığı

${ }^{70}$ Osman Tufan'nın verdiği bilgiye göre Nuri Çavuş, cahil fakat zeki bir adamdı. Jandarma iken eşkiyalık etmiş, becerikli, sözünü tanır, kendini sevdirir bir yaratılıșta idi. Çerkez olduğu için, Fransızlar Türkler aleyhine, kendilerine güç katsın diye Nuri Çavuş'u tutmuşlar ve mevki vermişlerdir. Bütün Çerkezleri ve Çerkez milislerinin seçimini ona bırakmışardı. Fransızların, Nuri Çavus'a verdikleri bu önemden yararlanmak için Cerkezler de, Nuri Çavuş'a yanaşmışlar, Nuri Çavuş, bir çok yerde Türklere yapılan zulümlerde komşuluk namına merhamet ederek "mutavassıt" rolünü oynamış ve mazlumları da himaye etmiştir; bkz. Tufan, a.g.e., s. 66.

${ }^{71}$ Abdullah Karamüftüoğlu Ailesi’nden....aynı dosya;

${ }^{72}$ Tufan, a.g.e., s.93. 
değerlendirmede, Kuva-yı Milliye'nin iç durumuna ve yapısına ilişkin sorunlarla ilgili ipuçları vermektedir;

"Haçın hala sükut etmemişti. Herkeste sabırsızlık başlamıştı. Komşu kuvvetler kumandanları, bir başa bağlanmamışlardl. Harekette iltihak yoktu. Bütün Adana cephesini idare edecek kuvvetli bir kumandana ihtiyaç vardı. Ali Saip Urfa'dan, Kılıç Ali Maraş'tan mebus olarak ayrılmışlar, Osmaniye mıntıkasına Binbaşı Recep Bey gelmiş, Karaisalt ve havalisinde Sinan Paşa çalışıyor. Fakat, hepimiz birbirimizden yüksek kahramanlık daiyesindeyiz, hareket birliği yoktu. Hatta bir cephede hareket yaptlırken, diğer cephede muzır bir atalet görülüyordu. Muhitte çetecilik ruhu sinmeye başlamıştı. Bizim cephede mevzii müsademelerden başka ciddi bir hareket yoktu. Hareket daha kuvvet ve şiddetle Antep cihetlerinde ciddileşmeye başlamıştı. Bizim cephede ciddi bir teşebbiuse geçmek için Haçın'ın sükutunu bekliyorduk. Haçın bir çok fedakarlıklara rağmen düşmemişti. Orast artık müzmin bir cephe halini altyordu. Doğan Bey, kü̧̈ük bir mesafede geriye gitse veya yer değiştirse derhal mahsur Ermeniler haber alıyor ve hemen huruç yaparak muhasirları dağıttyor ve köyleri tahrip ediyorlardl. Doğan Bey'in daima oraya bağlt kalması bir zaruret halinde idi" ${ }^{\prime 73}$.

Osman Tufan, Selahattin Adil Paşa'nın ve Kozan Mutasarrıfı Abdülaziz Bey'in gelişlerinin önemli bir açığı kapattığını belirtir. Fakat anılarının devamında, yine bölgedeki Kuva-yı Milliye'nin yapısında ortaya çıkan anlaşmazlık ve pürüzler dikkati çeker. Öyle anlaşılmaktadır ki, Osman Tufan ile Selahattin Adil ve Kozan Mutasarrıfı arasında oldukça belirgin bir uyuşmazlık vardır. Buna Osman Tufan şöyle değinmektedir;

"Fakat teessürle itiraf edeyim ki, ümit ettiğimiz gibi çıkmadı ve nedense, her ikisi ile geçimsizlik ettik. Bu zevat beni, garpta çeteci bir Demirci Efe, Çerkes Ethem ve saire gibi telakki ettiler ve iğfal etmeye, yalandan itibar göstermeye ve arkamdan da, müttefikan kurdukları planlarla kuvvetimizin inhilaline çalıştılar. Kaç defa kendilerine itaatımı ve Ankara'ya, Atatürk'e bağlılı̆̆ımı söyledim. Benden şüphe etmemelerini rica ettim. Bu ricalarıma karşı, yeni tedbirler düşündüler. Maateessüf düşündükleri tedbirler, bindikleri dall kesmek neviinden idi. Mutasarrıf, kendisinin Kürt olduğunu söyleyerek, Kürtleri maiyetinde topladı. Selahaddin Adil Paşa, zekasının vüsati ile arad, bana ve milli harekete muhalif ne bulduysa, kendisine yakınlaştırdı. Ceyhan suyunun şark kısmi, İbrahim Bey'in emir ve kumandasına tevdi edildi. Benim adresimi, Kilikya Şark Mıntıkası Kumandanı iken, Seyyar Müfreze Kumandanı diye ilan etti. Milli hareket başlangıcında hizmetleri görülenleri, birer vesile ile tahkir ve tezyif ederek küstürdü ve kaçırdı. Beni yalnız bırakmalarına yardım

${ }^{73}$ Tufan, a.g.e., s.95. 
etti. Bana, cepheden geriye gitmeyi adeta yasak ettiler. Geriden ekmek, cephane gelmez oldu. Cephedeki kuvvetlerin köylerinde tazyikler başladı. Bu hareketlerin manasını anlamak mümkün değildi. Doğan Bey'in, emirsiz gelen ve hüviyetleri meçhul bulunan bu şahıslara itaat edilmez demesi ve hatta yazdığt bir emirde, hareketlerini (yaptı̆̆ımız hayratı tahrip ettiler) cümlesi ile tavsifi, cidden yerinde idi. Ben, Ankara'dan arkadaşlarımdan hüviyetlerini sordum. Kendilerine vazife verilerek gönderilmiş olduklarını, hususi mahiyette ögrrendim ve itaat ettim. Selahattin Adil Paşa'nın benden gizli fikri şu idi: Artık, çetecilik bayatlamıştır. Yeni teşkilat ve ordu kuvveti lazımdır, kanaatında bulunduğu tahmin edilir. Bu fikrini beni, Demirci Efe zannettiğine göre, benden saklamakta haklıdır. Fakat benimle anlaşamazsa, eldeki kuvvetleri gücendirirse, bu fikrinde muvaffak olması imkansızdır. Esasen benimle beraber, bütün halk ve milli kuvvetler kumandanları, orduya ihtiyaç bulunduğunu müdriktirler ve bunu temenni etmekteyiz. Ancak, icra ciheti samimiyetle, elbirliği ile düşünmeye değer. Bu muhitin halkt, düşmandan gördükleri zulmü unutmamışlar ve istiklallerini, kendi kuvvetleri ile ve çok büyük fedakarlıkla kazanmaya ve bu uğurda her varlığını feda etmeye hazırlanmışlardır. Ordu teşkilatına mani olacak, bu arzuya muhalefet edecek tek kimse yoktu. Bu maksad, gizli planlarla, aldatıci hareketlerle meydana getirmek, halkın cevheri ile seciyesi ile istihza etmek demekti"74.

Halkın oluşturduğu Kuva-yı Milliye'nin bölgede kazandığı başarılar, beraberinde bir özgüven duygusunu da getirmiş olmalıdır. Çetecilik ruhunun güçlenmesi açısından oldukça elverişli olan bu bölgede, çeşitli çetelerden yararlanma yoluna giden Kuva-yı Milliye'nin komutanları ve elemanları, düzenli ordunun burada teşkilatlanması ve yeni atanan komutan ve yetkililerle hemen bir uyum içine girememişler ve bu durum sıkıntı yaratmıştır. Ancak bütün ulusal hareketi tehlikeye sokacak durumlardaörneğin iç ayaklanmalarda; Konya ayaklanmaları gibi- bölge Kuvayi Milliyesinden diğer cephelere kaydırılarak yararlanılma yoluna gidilmiştir.

Kuva-yı Milliye, 1921 yılı başlarına dek Adana cephesinde önemli başarılar elde etmiştir. Haçın (Saimbeyli) ve Kozan Ermenilerden arındığ 1 için, Ermeni Devleti kurma düşüncesi de ortadan kaldırılmıştır. Bu gelişmelerden sonra, bu bölgede tutunamayacağını ve bir sonuç alamayacağını anlayan Fransa, Ankara hükümetiyle görüşmelere başlamak istemiştir. 31 Mart 1921'de İnönü Zaferi'nden sonra Türk hükümeti, Fransa ile uygun koşullarda anlaşma olanağını elde etmiştir. Ankara hükümeti, bu bölgedeki Fransız hareketlerinin duraklamış olmasını fırsat bilerek Adana bölgesindeki birlikleri Batı Cephesi'ne kaydırmaya başlamıştır. Adana cephesindeki harekat bazı küçük birliklerle idare edilmiştir ${ }^{75}$.

\footnotetext{
${ }^{74}$ Tufan, a.g.e., s.98-99.

${ }^{75}$ Ener, a.g.e., s.275.
} 
13 Haziran 1921'de Ankara'da başlayan Türk-Fransız görüşmelerine kadar, 41.Tümen ile birçok milis kuvveti de Batı Cephesi'ne gönderildiğinden önemli bir faaliyet meydana gelmemiştir. Nizamiye kuvvetleri, 24 Mart 1921'de Batı'ya hareket etmiştir. Selahattin Adil Paşa'nın 2. Kolordusundan başka, Kuva-yı Milliye'nin müfrezelerinin de istenmesi üzerine, 2000 fazla kişi, 10-14 Nisan 1921 tarihinde Batıya hareket etmiştir. Bu şekilde 41.Tümen kadrosu yerine Adana Bölge Komutanlığı kurulmuş ve komutanlığına da Sağ Cenah Komutanı Yarbay Şemsettin Bey $\operatorname{atanmıştır~}^{76}$.

20 Ekim 1921 tarihinde imzalanan Ankara Anlaşması gereğince, Fransızlar tarafından boşaltılacak olan Adana çevresinde; Adana Vilayeti, İçel, Mersin, Kozan, Maraş, Cebel-i Bereket (Osmaniye) sancaklarını ve Urfa Sancağı'nın Fırat batısındaki Halep Vilayeti'nin Suriye sınırı kuzeyinde kalan kısımlarını kapsamak üzere, Tuğgeneral Muhittin'in emrinde kolordu yetkisiyle Adana ve Çevresi Komutanlığı kurulmuş ve bu bölge içindeki bütün kuvvetler bu komutanlığa bağlanmıştır ${ }^{77}$.

Mustafa Kemal'in emriyle, Kilikya Şark Mıntıkası Kuva-yı Milliyesini örgütleyen, oluşturan, Seyhan nehrinin doğusundan Maraş'a kadar uzanan ve Fransızların işgalinde bulunan bölgede görevini başarıyla tamlayan Osman Tufan, daha sonra Mustafa Kemal'in maiyetinde bulunmuş ve binbaşılığa terfi etmiştir. Batı Cephesinin önem kazanması üzerine, 2. Fırka'nın 127. Alay Kumandanlığına tayin edilmiş ve İzmir'e ilk giren kumandanlar arasında yer almıştır ${ }^{78}$.

\section{Sonuç}

Fransızlar sonu gelmeyen Çukurova direnişinden ve mücadelesinden yılmış ve siyasi gelişmelerin de etkisiyle anlaşma zorunluluğu duymuştur. Fransa, 20 günlük ateşkes uygulamasından sonra şansını yeniden denediyse de, ancak 20 Ekim 1921'de anlaşmaya varılmış ve Çukurova'nın boşaltılması kabul edilmiştir. Böylece 5 Ocak 1921'de Adana, 7 Ocak 1921'de de Osmaniye kurtulmuştur.

Güney'de başlayan bu mücadele, başta hemen hemen tümüyle halka dayanıyordu. Adana'nın Doğu cephesinde Kuva-yı Milliye'nin kuruculuğunu yapmış olan Osman Tufan Bey, 31 Mart olayından sonra İstanbul Emniyet Teșkilatının Eyüp Mıntıkası'nda görev almıș ve burada gösterdiği başarılar sayesinde İttihat ve Terakki erkanı tarafından takdir edilmişti ${ }^{79}$. Bu da Osman Tufan Beyin, doğrudan olmasa bile geçmişte İttihat ve Terakki ile dolaylı bir bağlantısı olduğunu göstermektedir. Ancak Çukurova Kuva-yı Milliye'sinin oluşumunda İttihat ve Terakki kökenli sivil

${ }^{76}$ A.g.e., ss.274-275

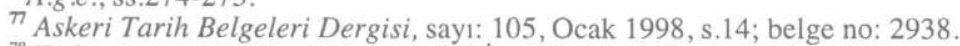

${ }^{78}$ Tufan, a.g.e.; "Albaylıktan emekli İsmail Cemal Akan Bey'in Osman Tufan Paşa'nın Biyografisi Hakkındaki Yazısı", s. 15-16.

${ }_{79}$ Tufan, a.g.e,; Ahmet Kemal İlkul, "Illksöz”, s.19. 
ve askeri bürokratların rolü çok sınırlı görünmektedir. Oysa Batı Anadolu Kuvayi Milliye örgütlenmesinde İttihat ve Terakki'nin rolünün çok daha belirgin olduğu bilinmektedir ${ }^{80}$.

Müdafaai Hukuk ve Kuva-yı Milliye'nin oluşturulmasında askeri desteğin çok geciktiği ve her şeyin yoktan var edildiği anlaşılmaktadır. Bu konuda Kılıç Ali Bey'in Mustafa Kemal'e, Köçeki'den gönderdiği 17 Nisan 1920 tarihli yazıda yer alan şu satırlar bunu çok iyi anlatmaktadır;

"Daha önce bildirdiğim gibi her türlü yardımdan mahrum olarak araçsız, mühimmatsız bir kuvvetle, düşmanla uğraşmak Kuvayı Milliye'ye bir başarı sağlamasından çok bozguna uğratacă̆ üzülerek arzolunur. Destek ve araç gereç için nereye müracaat ettimse hep aksi cevaplar aldım. Bir türlü yardım alamadım. Maraş'ta olduğu gibi bu havaliye de yardım edilmeyecekse Kuva-yı Miliye harekatı başartyla sonuçlanamayacaktır. Bundan dolayı Maraşve havalisinde kazanilan başartyı lekelemektense şeref ve haysiyetle bu vazifeden çekilip gitmenin daha mertçe olacağını düşünüyorum. Allah'ın yardımı ve şahsi faaliyet ve azmimden başka yardımctm olmadı̆̆ından milli amacın gerçekleştirilmesi istenmekte ve gerekli ise etkili bir yardımın bir an önce verilmesi aksi halde önceden beri çektiğimiz sıkıntılara bir hezimet daha eklememek için bırakıp gitmeme izin verilmesini rica ederim $" 81$.

Halk büyük bir askeri gücün gelerek kendilerini kurtarması beklentisi içindeydi. Böyle bir gücün gelmekte olduğuna halkı inandırmak, onları milli davaya kazandırma yönünde etkili olmuştur ${ }^{82}$.

Kasım Ener, Adana Cephesinin askeri birliklerle güçlendirilemediğini, bu durum karşısında Kuva-yı Milliye'nin, makineli tüfek ve top ihtiyacını giderme çabası yerine, Genelkurmay Başkanlığı'nın hareketsiz kalışının hayret verici olduğunu belirtir. Oysa Güney Kuva-yı Milliyesi, gerçek anlamıyla halk kuvveti olup, Kuva-yı Milliye komutanlarının bölgede tanınan hatırlı kişiler ve subaylar olduklarını da söyler. Kasım Ener, Çukurova Kuva-yı Milliye'sine istenen askeri desteğin gelmeyişini, Genelkurmay'ın, Çukurovalı Kuva-yı Milliye'nin zorbalığa, eşkıyalığa girişecekleri veya Adanalıların ayrı bir hükümet kuracakları yolunda bazı kuşkular ve bir güvensizliğin mi söz konusu olduğunu eserinde tartışmaktadır. Oysa yıllar sonra İsmet İnönü'nün kendi deyimiyle, Güney Cephesindeki direniş ve kurtuluş azmi Batı Cephesi üzerinde büyük bir etki yapmıştır. $^{83}$

${ }^{80}$ Köklü bir örgütsel deneyimi olup, dayanıssma ağını Ege yöresinde de yaratmış olan İttihatçılar başta olmak üzere Ulusçular, bölgesel direnişi oluşturup sürükleyecek kurumları olusturmak amacıyla, İzmir'in işgali sonrasinda hemen harekete geçtiler. Pek çok subay ve sivil memur, yerli ileri gelenlerle bir araya gelerek, yerel komiteler kurdular.

${ }_{81}^{81}$ Askeri Tarih Belgeleri Dergisi, sayı: 103, Ocak 1997, s. 122; belge no. 2893.

${ }^{82} \mathrm{Bkz}$. Tufan, a.g.e.

${ }^{83}$ Ener, a.g.e., s.160-161. 


\section{KAYNAKÇA}

Abdullah Karamüftüoğlu Ailesi'nden Cezmi Yurtsever tarafından alınan belgeler; Tayyıpoğulları Dosyası.

Ahmet Cevdet Çamurdan, Kurtuluş Savaşı'nda Doğu Kilikya Olayları, Adana, 1969.

Ali Saip Ursavaş, Çukurova Faciaları ve Urfa'nın Kurtuluşu, Kastaş A.Ş.Yayınları, İstanbul, 1988.

Alptekin Müderrisoğlu, Kurtuluş Savaşı'nın Malî Kaynakları, Atatürk Araştırma Merkezi Yayınları, Ankara, 1990.

Askeri Tarih Belgeleri Dergisi, sayı: 18, 103, 104, 105.

Atatürk, Söylev, Cilt I-II, Türk Dil Kurumu Yayınları, Ankara, 1978.

Bige Yavuz, Kurtuluş Savaşı Döneminde Türk-Fransız Illişkileri 1919-1922, Türk Tarih Kurumu Yayınları, Ankara, 1994,

E.Brémond, La Cilicie en 1919-1920, Imprimerie Nationale, Paris, 1921.

Gotthart Jeaschke, Türk Kurtuluş Savaşı Kronolojisi, Cilt.1, Ankara, 1970.

Harp Tarihi Vesikaları Dergisi, sayı.13.

Hulki Saral-Tosun Saral, Vatan Nasıl Kurtarıldı, İş Bankası Yayınları, Ankara, 1970.

Kasım Ener, Çukurova Kurtuluş Savaşında Adana Cephesi, Türkiye Kuva-yı Milliye Mücahit ve Gazileri Cemiyeti Yayınları, Ankara, 1970.

Kemal Çelik, Milli Mücadele'de Adana ve Havalisi (1918-1922), İstanbul Üniversitesi Sosyal Bilimler Enstitüsü Türkiye Cumhuriyeti anabilim Dalı, Doktora Tezi, İstanbul, 1993.

Mustafa Onar, Atatürk'ün Kurtuluş Savaşı Yazışmaları, Cilt.1, Kültür Bakanlığ1 Yayınları, Ankara, 1995.

Nimet Arsan, Atatürk'ün Tamim Telgraf ve Beyannameleri, Atatürk Araştırma Merkezi Yayınları, Ankara, 1991.

Osman Tufan., Kilikya Doğu Bölgesinde Milli Hareketler ve Kozan Sancă̆ı ile Mülhakatının Kurtuluş Hatıraları, Bahar Matbaası, Ankara, 1964.

Selahattin Tansel, Mondros'tan Mudanya'ya Kadar, Cilt I, Milli Eğitim Bakanlığı Yayınları, Ankara, 1977.

Seviye Solak, Horasan'dan Çukurfenk'e ve Dikirli-Karamüftüoğlu'nun Yarım Kalan Notları, Taş Medrese Yayınları, Erzurum, 1999.

Tevfik Coşkun, Kadirli Milli Mücadelesi ve Hatıralar, Kadirli Basımevi, Kadirli, 1967.

Türk Istiklal Harbi, IV. Cilt, Güney Cephesi, Genelkurmay Başkanlığı Harp Dairesi Resmi Yayınları, Ankara, 1966.

Uluğ İğdemir, Sivas Kongresi Tutanakları, Türk Tarih Kurumu Yayınları, Ankara, 1969. 